\title{
A Re-appraisal of the Stratigraphy, Palaeontology and Dating of Cow Cave, Chudleigh, Devon, England.
}

\author{
Jim W. Simons
}

\begin{abstract}
:
Simons J.W. 2010. A re-appraisal of the stratigraphy, palaeontology and dating of Cow Cave, Chudleigh, Devon, England. International Journal of Speleology, 39 (2), 113-135. Bologna (Italy). ISSN 0392-6672.

Cow Cave is an important Quaternary paleontological site in Chudleigh Gorge, Devon, UK., now known to have a sequence of cave-earths and stalagmite floors that range in age from Upper Middle Pleistocene ( MIS 7 interglacial) through to the Holocene (Flandrian) and the present day. Excavations in 1927-1934, and again in 1962-3, have provided a rich fauna, with some artefacts. Here, the stratigraphy of the deposits is now more fully described and the faunal remains are considered in their stratigraphical contexts. Data supporting the existence of former cave entrances are presented along with an analysis of the processes of sedimentation and taphonomy with their climatic interpretations. Based on recent U-Th dating of a critical Stalagmite horizon, a chronology of the mid-Pleistocene to Holocene sequence is discussed. Finally, further excavation in Cow Cave and nearby sites is recommended.
\end{abstract}

Keywords: Cow Cave, Devon, UK, Pleistocene, Stratigraphy, Fauna, U-Th dating

Received 11 April 2010; Revised 24 May 2010; Accepted 10 June 2010

\section{INTRODUCTION - HISTORICAL BACKGROUND}

The caves of Chudleigh Gorge, Devon, have been known for over 400 years, being mentioned in Risdon's 'Survey of Devon' [1605-1630] (Risdon, 1811; Youings, 1966) and both fossil and archaeological remains have been recovered from them since the mid-1700s as quarrying activities broke through into fissures (Swete, 1794, p.101-109; Polwhele, 1797, p.134). The caves attracted the attention of several renowned cave pre-historians of the $19^{\text {th }}$ Century, with Dean William Buckland examining several fissures as early as 1823 (Buckland, 1823, p.69). Buckland excavated in Pixie's Hole around 1825 (Anon, 1825) and this was followed by deeper excavations by the Reverend J. McEnery and T.Northmore sometime between 1825 and 1840 (McEnery, 1829-1841, 1859; Northmore in Blewitt, 1832; Pengelly, 1873). Their work basically established the depositional sequence of a basal stream-laid gravel, followed by cave-earths containing a Pleistocene fauna of bear, hyena, deer and elephant, one (or two) "stalagmite" floors (note: in all these old reports the term "stalagmite" refers to what we now call flowstone), and a level with charcoal, 'flint knives', pottery and bones of ox and red deer of Holocene age. The earlier bone discoveries at Chudleigh and this work in Pixie's Cave was later summarised by another

P.O. Box 218, 90121 Emali, Kenya (formerly Department of Palaeontology, British Museum of Natural History, London), E-mail: sikitoi.francoise @ gmail.com of Devon's eminent cave scientists, William Pengelly (Pengelly, 1873), who is particularly recognised for his methodical excavation methods in nearby Kents Cavern (Lundberg \& McFarlane, 2008). Despite this early interest, it is surprising that Cow Cave with its imposing entrance not far along the valley, failed to attract these early Pleistocene savants, although fossil remains must certainly have been known to occur there since it is now believed the cave had already been broken into by quarrying in the mid-1700's. It was not until 1927 that any serious digging in the Cow Cave deposits occurred. This was undertaken by the Torquay Natural History Society from 19271934. Unfortunately the dig was generally poorly documented; however, Beynon's report (1934) did provide the first indication that the Cow Cave deposits were of some antiquity with a rich and climatically varied Pleistocene fauna.

Other cave studies at Chudleigh have been sporadic. Sometime around 1915, and again later in the mid1940 's, A. S. Kennard collected material from an unspecified 'Rock Shelter' or 'fissure' and obtained a large collection of micro-fauna, mainly rodents, birds, and amphibians, which are preserved in the British Museum of Natural History (BMNH - now called simply the Natural History Museum, London). This collection included a fossil lemming Dicrostonyx guiielmi [now D. torquatus] (Hinton, 1926) and a pika that might indicate elements of a Pleistocene date, while other bones were of pig, ox and red deer that were considered to "suggest human occupation"(Bell, 1915) and may infer that a later Holocene horizon was 
also present. Over 65 species of birds were identified that included grouse and ptarmigan, both elements of a cold moorland habitat (Bell, 1915, 1922; Newton, 1923).

Tramp's Cave, lower down on the south side of the gorge, was excavated by M. Collins in 1962-3 who reported a series of soil horizons and a stony caveearth beneath a stalagmite floor that yielded charcoal, some worked flint blades, and a fauna that included a large deer, ox (Bos), horse, rodents, amphibians and birds (Woolner, 1963), for which no age was provided. Of particular significance in the talus outside the cave, however, was that the series extended down to water-laid gravels similar to that in both Cow Cave and Pixie's Hole. An extension of this cave was revealed in the, now disused, nearby Palace Quarry that was entirely filled with stream deposits but was inaccessible in 1963 and remains unexamined.

Pixie's Hole has also been re-excavated more recently as part of a PhD thesis by Simon Colcutt (1984) and this research has added stratigraphic detail to the work of Buckland and McEnery. It has shown the existence of a Pleistocene sequence comprising a basal layer of sand and gravel beds with rare fauna and, sandwiched between two stalagmite floors, a series of cave-earths that contained mammalian fauna throughout as well as a level towards the top with a Late Upper Palaeolithic industry. Holocene layers occurred above the sequence (Colcutt, 1984).

Various remains have also been recovered, or noted to occur, in several other Chudleigh Caves or fissures, including Chudleigh Cavern and Rock Garden Cave in the old quarries forming the grounds of Rock House (Oldham et al, 1972), sites that have yet to be fully examined.

This writer was introduced to the Pleistocene deposits and faunas of Devon Caves by the late Antony Sutcliffe of the Natural History Museum, London. As a follow-up to the earlier pioneer work of Trevor $\mathrm{R}$. Shaw (Shaw, 1949a, 1949b), the writer undertook speleological work on the caves in the Gorge, such as in Clifford's Cave during 1959-1961 (Simons, $1960,1961,1963)$, with the study culminating in the investigation of Cow Cave between 1961-1963, the results of which have never formerly been reported in detail. This present manuscript documents the findings from the study of the sediments and fauna. The results of the speleogenetic study are not yet published.

\section{THE CAVE}

Cow Cave is a segment of a larger phreatic system in a small outcrop of Devonian Limestone that includes the nearby, larger and renowned, Pixie's Hole high up on the North side of Chudleigh Gorge. These cave passages are largely controlled by north-south and east-west trending joints with some development along easterly-dipping bedding planes. Valley downcutting later drained the phreatic zone exposing the caves and both were invaded and modified in their lower parts by stream action which was then followed by the deposition of cave-earths and calcite deposits within. Prior to, or during this period, some jointplanes in the caves and elsewhere in the limestone were subjected to minor displacements that widened existing joints and created additional rift passages or caves.

The cave lies at the western end of the gorge in cliffs that were quarried during the $18^{\text {th }}$ century (Fig.1). Its present entrance (national grid reference, NGR, SX $86467867, \sim 55 \mathrm{~m}$ above Ordnance Datum and $\sim 25 \mathrm{~m}$ above the present level of the Kate Brook) has probably been enlarged through quarrying and is $5 \mathrm{~m}$ wide by $4.5 \mathrm{~m}$ high. A bare rock floor at the entrance, devoid of any sediment in 1962-3, extends from just outside the portal for $3 \mathrm{~m}$ into the cave where it abuts with a square raised rock platform that has a decidedly unnatural appearance (Fig. 2).

Both the rock floor and platform do not extend across the full width of the passage, there being a 'channel', 1-2 m wide between them and the west wall. This sediment-filled channel also runs beneath a long overhanging buttress that protrudes from the west wall almost half-way across the passage at the rock platform. The upper part of the entrance passage is elliptical in cross-section being a solution tunnel formed along a bedding plane, dipping from west to east at a 15 degree angle, while the lower half forms a vadose-like 'trench' with a ledge along the east wall representing the lower continuation of the sloping bedding-plane (see cross section Fig.14).

From the roofed part of the cave entrance, the main

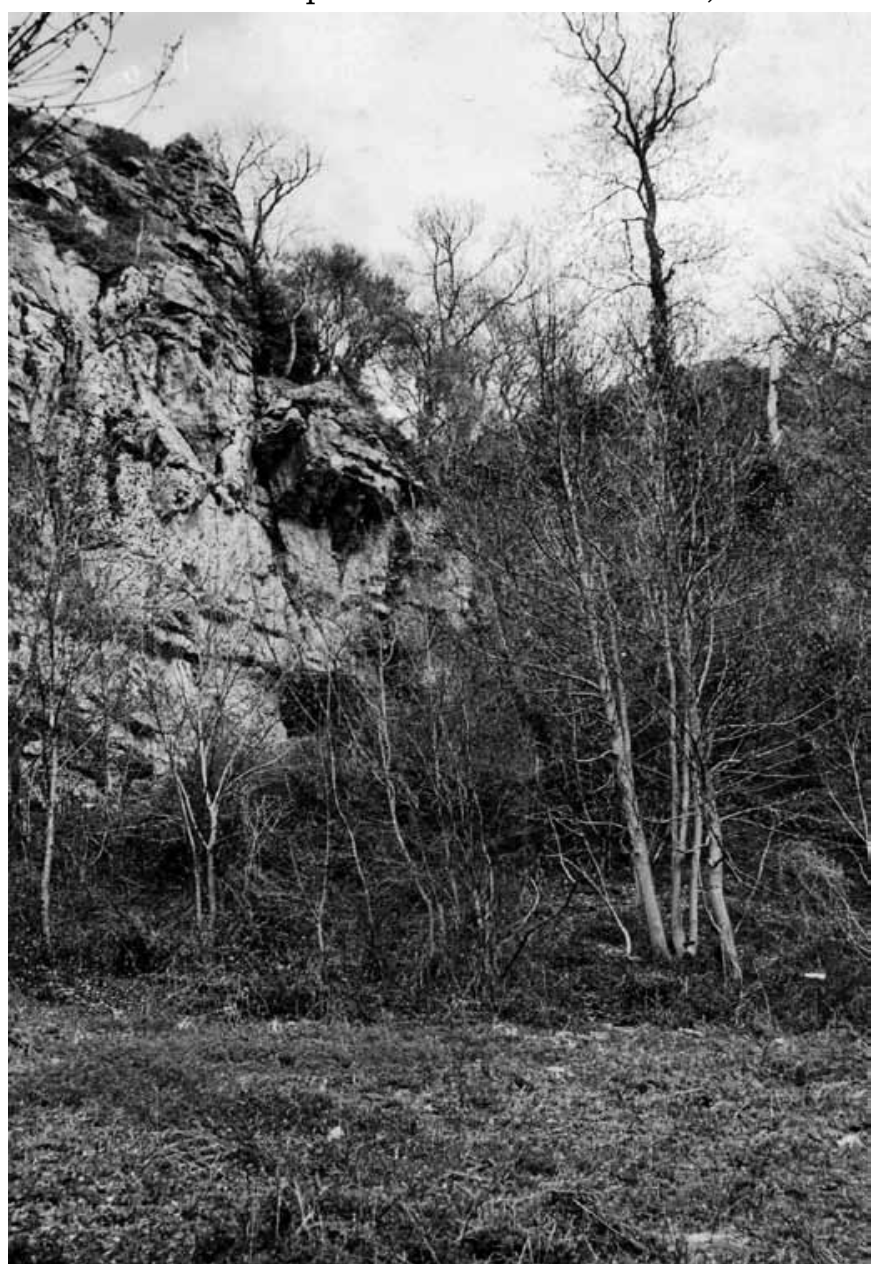

Fig.1. The entrance to Cow Cave in the quarry face at the western end of Chudleigh Gorge. 


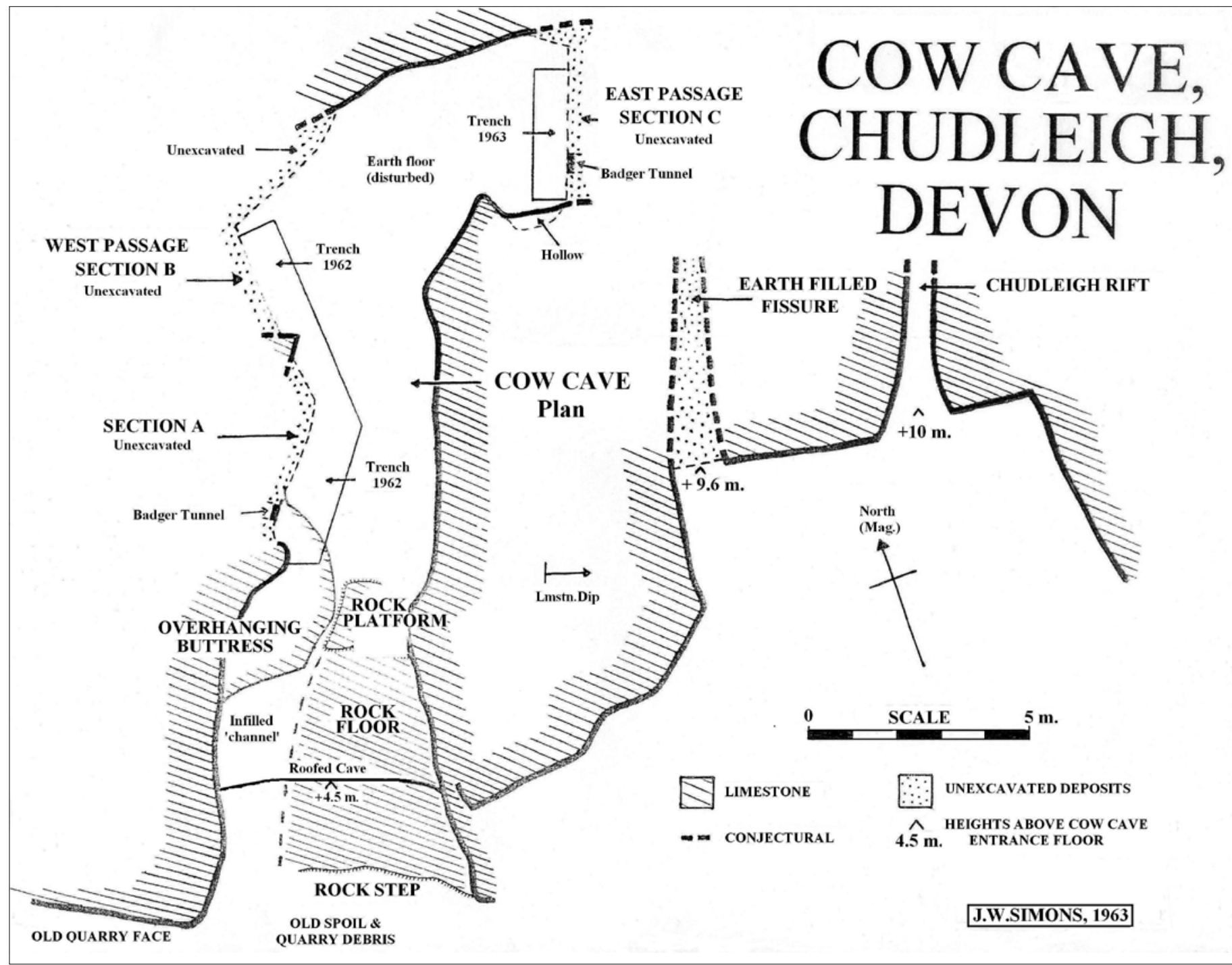

Fig.2. Plan of Cow Cave, together with nearby entrances, showing remnant sections of sediment infill examined in 1962-3.

tunnel extends north for around $14 \mathrm{~m}$ and, beyond the overhanging buttress, exhibits remnant exposures of deposits along the west wall (Figs.2-3). The tunnel is then intersected by an east-west trending passage forming a T-junction. The right (eastern) branch runs for $5 \mathrm{~m}$ to a sediment choke where the ribbed northern wall slopes upwards to a joint-plane giving the passage a more triangular cross-section in its upper part. The less obvious western continuation is immediately filled with deposits and the flatter roof here exhibits several solution tunnel pockets.

The entrance to a small nearby cave, known as Chudleigh Rift, lies in an embayment in the cliffs, $12 \mathrm{~m}$ east and $10 \mathrm{~m}$ above the present rock entrance of Cow Cave. Between the two caves there is also a similar fissure, exhibiting signs of displacement, which is entirely filled with earth. Of the two entrances into the Pixie's Hole complex, the nearest lies $\sim 40 \mathrm{~m}$ to the east and Cow Cave is believed to be an extension of the westernmost series of passages of this cave, that are also sediment-choked, with only $\sim 12 \mathrm{~m}$ separating the two (Colcutt, 1984, p.886).

\section{THE 1927-1934 EXCAVATIONS}

The Archaeological Section of the Torquay Natural History Society commenced excavations at Cow Cave

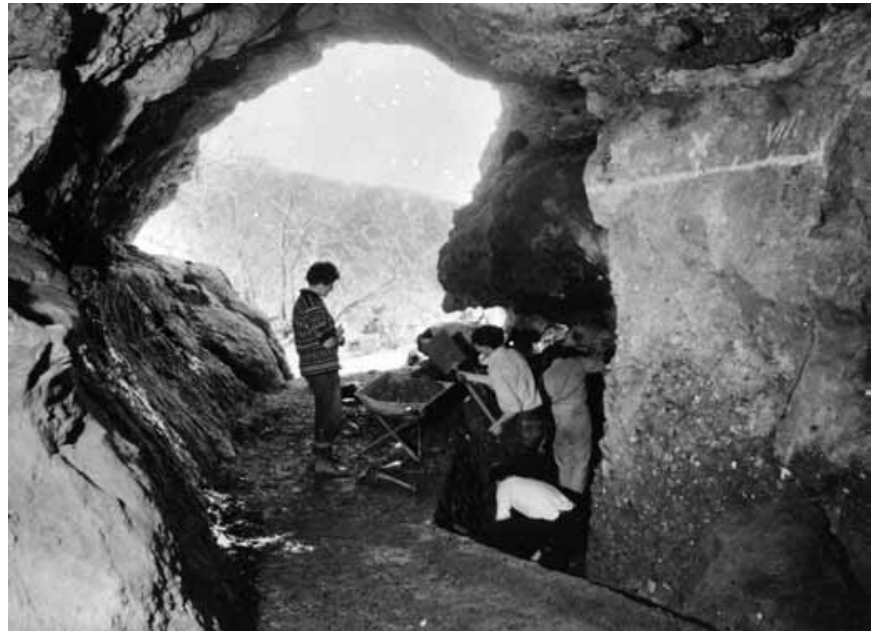

Fig.3. The Main Passage with trenching along Sections A and B (Note the 'quarried' overhanging buttress near the entrance).

in the latter part of 1927 and their work continued sporadically until late in 1934, totalling 60 days. Results of the findings up to that time were then described (Beynon, 1934).

At the commencement of work, the Pleistocene sediments were found to occupy the interior of the cave as a segment abutting the west wall and largely 
filling the east-west passage. A substantial amount that had already been earlier removed centrally along the main entrance passage was at that time attributed to natural causes rather than to quarrying activities. The report also refers to a remnant of "stalagmite"capped breccia along the east wall and a sketch plan of the cave does indicate some deposit upon the ledge in the vicinity of (or beyond) the rock platform and buttress, but in this respect the drawing is somewhat vague (Beynon, 1934, p.128). Also, at that time, a "limestone soil" deposit, with vegetable matter and bones of recent domestic animals and birds, was recorded as covering the entrance vestibule and extending into the cave where the earlier deposits had been removed.

Beyond recognising that part of the Pleistocene sediments were water-laid and were derived from the Haldon Hills, that they could be separated into 'uncemented' (i.e. lower Stream Deposit) and 'cemented breccia' (upper cave earths), and that a stalagmite floor may once have covered the sequence, it is unfortunate that no apparent attempt was made to detail the stratigraphy as excavations progressed, or to record from which levels the fossil finds were recovered. This was especially regrettable since, despite noting the relative abundance of the various mammal species present, the specimens included remains that may have come from differing climatic periods and flint artefacts from widely separate periods in time. The mammal remains were listed in order of abundance as: bear, wolf, fox, hyena, deer, badger, wild cat, Irish deer, ox, bison?, goat or sheep. Humans, rhinoceros and beaver were later added to the list. Eight flint artefacts were recovered with one backed blade being referred to the Azilian industry, now identified as Creswellian (R. J. Clarke personal communication). The entire collection is housed in the Torquay Museum, Devon, England.

\section{THE 1961-3 RE-INVESTIGATION}

Cow Cave is an example of one of the many caves with Pleistocene deposits and faunas in Great Britain that have earlier been excavated without detailed attention being paid to the stratification of the in-fills, the exact levels of the remains in them not being systematically recorded, and the results being inadequately reported. The 1961-1963 reinvestigation of Cow Cave was therefore undertaken to determine the details of the deposits remaining in the cave, to obtain any representative fossils from the identifiable strata so as to possibly determine from which horizons the 1927-1934 material was obtained, and hopefully to place the strata and fauna within stages of the Pleistocene Period. The study commenced in 1961 with an examination and identification of the remains preserved in the Torquay Museum Collection, which continued until 1963. A field investigation in the cave was conducted in two short seasons in 1962 and 1963, but, since this was not intended as a reexcavation of the cave per se but rather to gather more informative data through a 'clean-up' exercise, only minor new excavation was done.

\section{RESULTS 1 - THE STRATIGRAPHY}

Remnants of the sediments in the cave in 19623 occupied only two sections along the west wall (Sections A-B), and within the eastern passage (Section C). None remained along the east wall of the main passage. There were no deposits covering the rock entrance vestibule and the floor of the interior was of disturbed material that had accumulated since the 1927-1934 excavations.

The western sections were divided into two areas, the deposits at both filling the cave up to their localised roofs (Figs.4-6). Section A ran from below the overhanging-buttress (in part), and then beyond the buttress to outcropping limestone that formed the southern wall of the western branch. It seems unlikely that more than $1 \mathrm{~m}$ of deposit now remains as a veneer against the wall in this sector. An area of the deposits at Section B was exposed to a width of $2.5 \mathrm{~m}$, but unexcavated material along the northern wall indicates that the passage is almost $4 \mathrm{~m}$ in width. The sediments infilling the East Passage at Section C (Figs.7-8) that is a little over $3 \mathrm{~m}$ in height, occupied the full $4 \mathrm{~m}+$ width of the passage and most of its central area was more fully exposed leaving some un-excavated materials on either side.

Trenches (0.6 $\mathrm{m}$ deep) were sunk into the existing cave floor along all sections to determine, if possible, the depth of the deposits and as a prelude to section drawing (See Fig.3). These were later back-filled. Sections A and B were cleaned to further reveal the stratigraphy and interpretations of the strata are based upon field data and detailed photography. Since it demonstrated a greater and more illuminating sequence of strata in which fossil remains were more evident, Section $\mathrm{C}$ was cut back by $1 \mathrm{~m}$ and drawn in detail. This particular section has provided the clearest understanding of the sequence of sedimentation and climatic events within the cave. It is therefore used as a basis for comparison with the sediments in the other sections. The sequence of deposits now recognised in the cave, in ascending order, is as follows (see summary in Table 5).

\section{Stream Deposit (All sections)}

The basal layer within the cave (Field Layer 6) is a water lain gravel, consisting largely of flints with a few isolated limestone rocks and boulders. It is fairly homogenous throughout, except at Section C where it varies slightly by having a more greenish horizon below a large limestone boulder in the lower right of the exposure, perhaps due to a larger amount of green slate, than in its brownish upper part.

A macroscopic analysis of the gravel (Dept. of Mineralogy, BMNH) showed that the matrix is predominantly comprised of bleached flint pebbles, some of which are derived Cretaceous fossils (such as Echinoderms), glauconitic sandstones and sandy cherts from the Upper Greensand, and pieces of slate from the Carboniferous or Devonian. More sporadic are Palaeozoic siltstones, possible tourmalised slates 


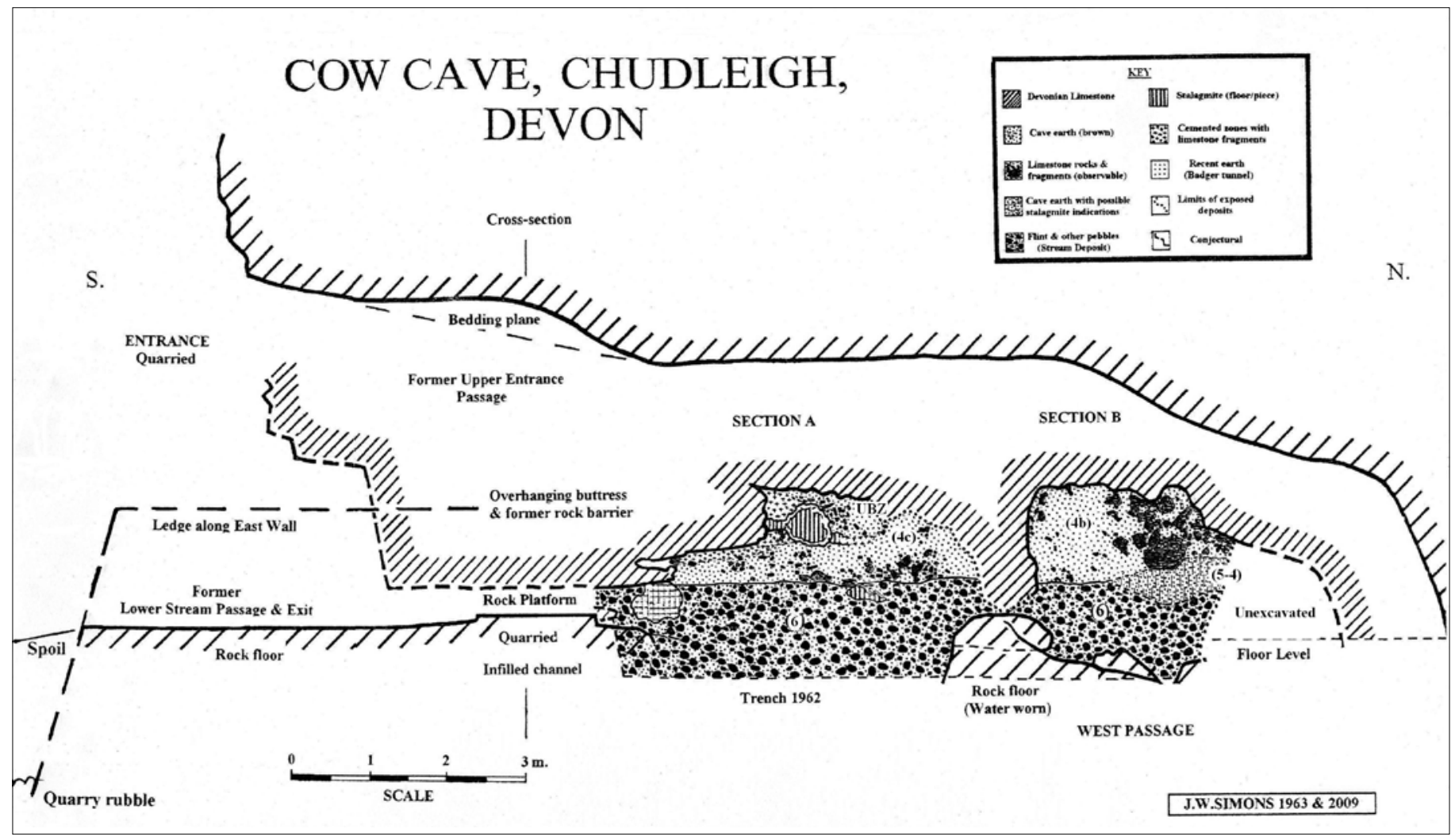

Fig.4. Longitudinal profile of the Main Entrance Passage showing remnant sections of sediments along west wall and infilling the West Passage in 1962-3, together with information on assumed former entrances (interpretation based upon field data and photographic record).

and hornfelses from the metamorphic aureole of the Dartmoor Granite, and one (feldspar-bearing) quartztourmaline pebble occurring in situ only within the Dartmoor Granite Pluton. All such materials are still to be found in the bed of the present stream and they have been derived from the Eocene gravels that cap the Haldon Hills, $5 \mathrm{~km}$ to the north of the gorge, which is the source of Kate Brook. Both MacEnery (1859) and Beynon (1934) were correct in recognising this as the origin of parts of the Pixie's Hole and Cow Cave deposits.

The surface aggradations of the Stream Deposit are basically at the same level at all sections at a height of $0.5 \mathrm{~m}$ above the cave entrance platform. At Section $\mathrm{B}$ the water-worn limestone forming the floor of the West Passage was exposed by the trenching and the stream gravel is only $1 \mathrm{~m}$ in thickness. However, bedrock was not reached at either Sections $\mathrm{C}$ or A, where the stream deposits were exposed to the base of the trenches, to $1.1 \mathrm{~m}$ and $1.25 \mathrm{~m}$ respectively. A probe at Section C, also without reaching bed-rock, confirmed at least another $1 \mathrm{~m}$ depth to indicate that the gravels are in excess of $2 \mathrm{~m}$ in thickness in the main passages. As earlier noted, the Stream Deposit fills the channel extending from the overhanging buttress out to the entrance vestibule.

Broken bones of brown bear were recovered in situ at Section C, but only within the topmost (0.6 $\mathrm{m})$ part of the deposit. The bones are of a whiteyellowish hue and are 'polished' in appearance. Other remains included hare, lemmings, voles and fox. A few specimens of bear, wolf, northern or root vole, and various non-identified rodent teeth, were sieved from in situ material from the trenches along Sections
$\mathrm{A}$ and $\mathrm{B}$. The lemmings and northern vole indicate a cold period for this level. A large piece of 'fluted' flowstone or drapery, believed broken as a result of frost action, was also recorded buried into the top of the stream material in the mid-part of Section A (See Fig.5).

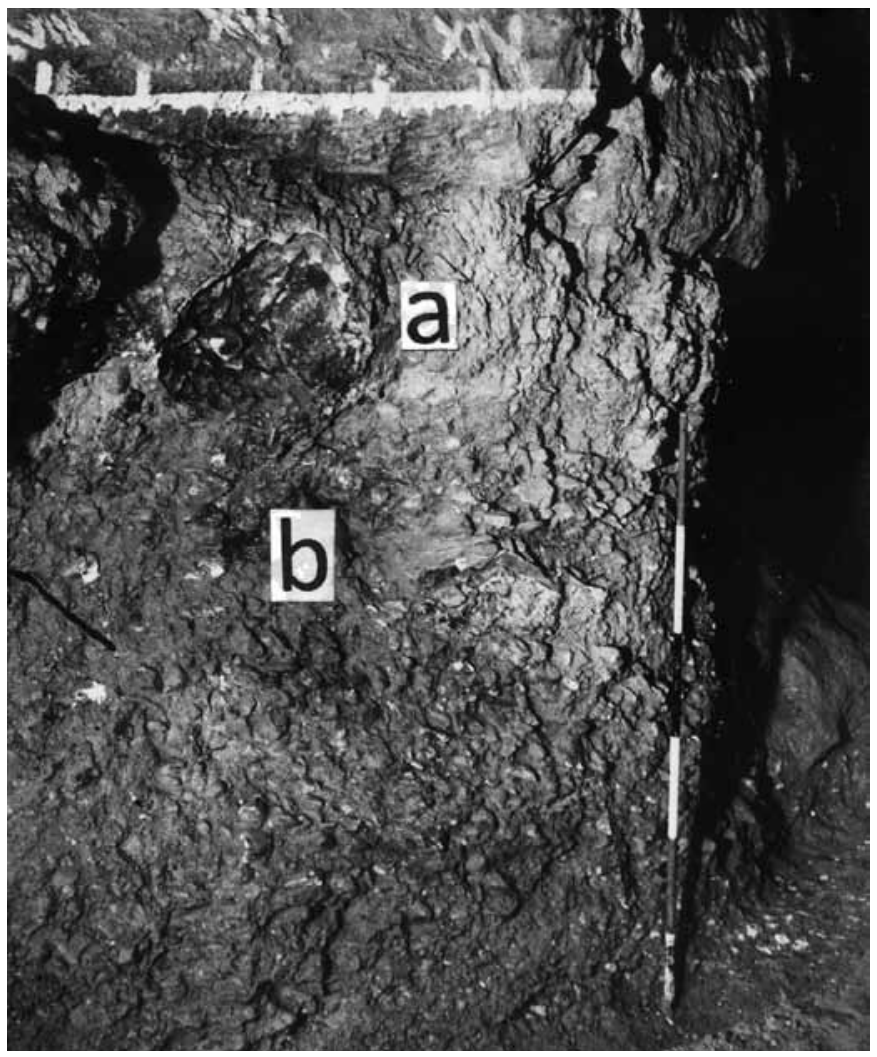

Fig.5. Part of Section A - showing intervening flowstone Floor 3c (a) and flowstone piece in-bedded in the Stream Deposit (b). 
Of particular note, was the recovery of a single, patinated, water-worn and frost-pocked flint flake, also within the upper part of the deposit in 'the hollow' at Section C (Fig.2), "that looks like a flake from a Levallois core of Lower-Early Middle Palaeolithic age" (R. Jacobi, personal communication, in Lundberg, et al., 2008).

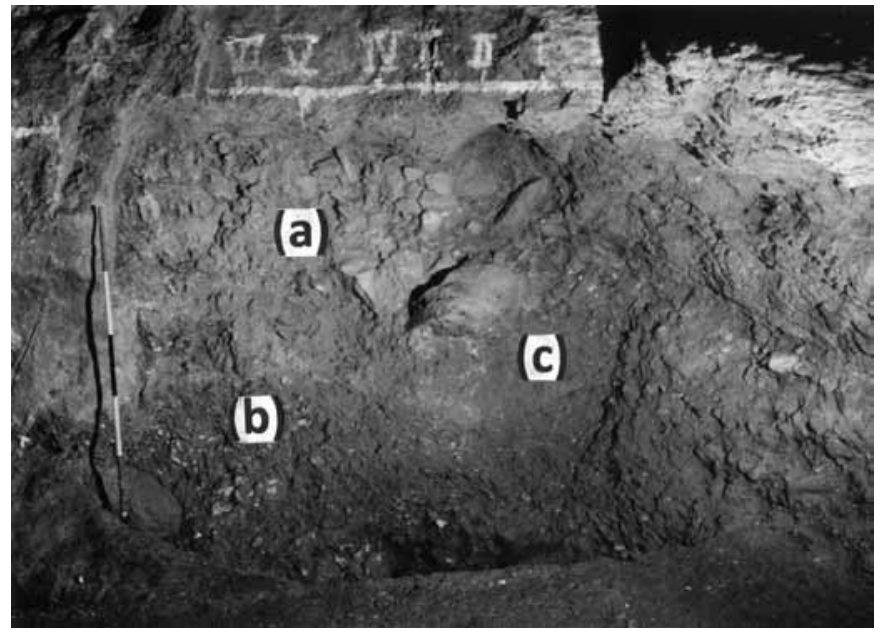

Fig.6. Section B - filling the West Passage (Note rocks and large boulder in-fill (a), junction of cave-earth with the Stream Deposit (b) and possible Transition Zone beneath large boulder (c).

\section{Broken Stalagmite Floor Zone (Section C only)}

Directly upon the stream gravel at Section $\mathrm{C}$ is a zone that represents a severely broken and shattered stalagmite floor (Field Layer 5). This horizon stretches across the East Passage and reaches $0.8 \mathrm{~m}$ in thickness and is here considered as two distinct units separated in time:

\section{Stalagmite Floor 1}

On the left (north) side of the section is a thick crystalline mass (Field Layer 5a) which probably represents the original stalagmite floor before upheaval took place. This lies directly upon the stream gravels in this sector, but is absent from Sections A-B suggesting that it must have petered out as a solid floor westwards along the passage. This floor clearly indicates a major temperate period within the middle sequence of deposits in the cave. It is this layer that was sampled in 2006 and the U-Th dates (Lundberg et al., 2008) provide the basis for relative dating of the deposits above and below.

\section{Broken Stalagmite Floor Facies}

Above the remnant floor and across the remainder of the section, this zone $(5 b)$ is composed mainly of

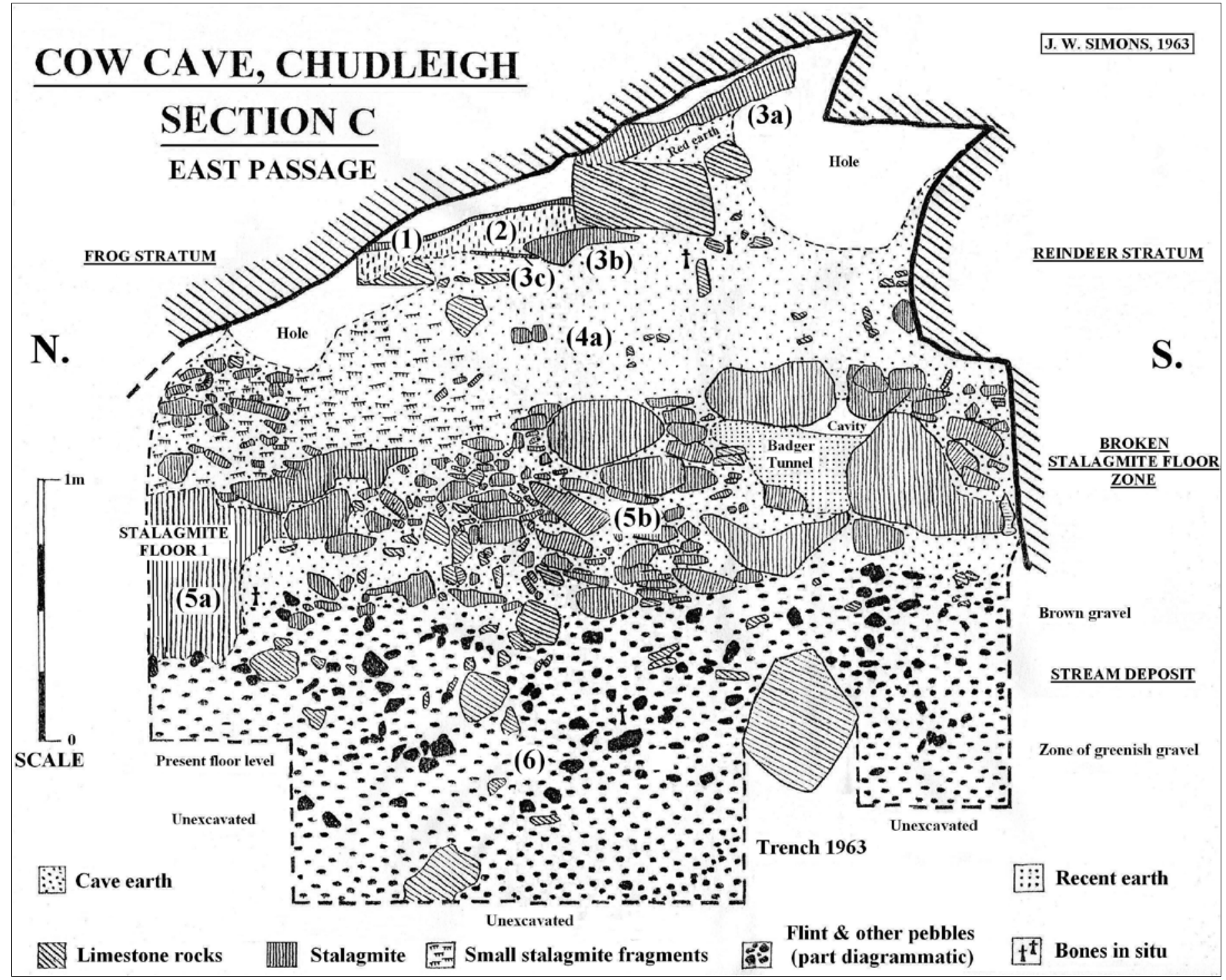

Fig.7.Stratigraphy of the sediments infilling the East Passage at Section C (Measured field drawing). 


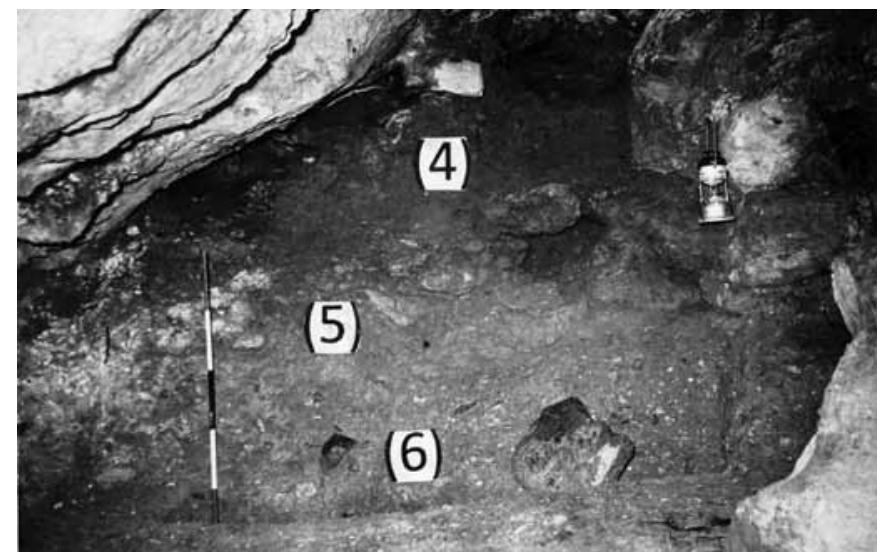

Fig.8. Section $\mathrm{C}-$ filling the East Passage (Note Broken Stalagmite Floor Zone - Layer 5 -between the Stream Deposit -Layer 6 - and Reindeer Stratum - Layer 4).

fragments, small angular rocks and large boulders of stalagmite up to $0.5 \mathrm{~m}$ by $0.25 \mathrm{~m}$ in dimensions. A few are inclined at angles and some appear to have been broken and then re-cemented. There are also occasional limestone rocks. The spaces between the blocks are filled with a cave earth essentially similar to the next layer above. This Broken Stalagmite Floor Facies is also absent at Sections A-B, apart from the single piece of flowstone at Section A. Beynon (1934, p.132), however, did record the occasional presence of large pieces of stalagmite bosses (as well as stalactites) in the deposits and, as these must have occurred within the sediments above the Stream Deposit, they are also probably isolated representatives of this stratum.

It was at this stage that breakage and upheaval of the floor took place during a period of intense frost action, perhaps together with minor earth movements in the limestone for which evidence exists. The broken stalactites further support the evidence of frost action at this time. This stage marks a climatic deterioration and the onset of the arctic conditions as indicated by the fauna of the next level above.

A few bones of wolf and bear were recovered from the cave earth between the broken stalagmite fragments at Section $\mathrm{C}$ and one deer humerus (presumably of reindeer since the species is characteristic of Level 4 above) was found cemented into a stalagmite piece. These may have been introduced following the fracturing of the floor below, infill of the spaces between the blocks, and some re-cementation of the broken stalagmite pieces.

\section{Transition Zone (Section B only)}

The only possible representative of Field Layer 5 on the western side of the cave is at Section B where a faint whitish 'line' on the left of the section, at the top of the Stream Deposit, runs to an area of cave earth that lies beneath a boulder and large rocks at the right of the section (shown on Fig.4 as (4-5)?). Although otherwise similar to that in the rest of the exposure, this earth is relatively free of limestone pieces and also contains whitish inclusions. It is considered that these might represent 'powdered' stalagmite carried further down the passage as a result of the break-up of Stalagmite Floor 1. For the time being, the zone is considered as a cold transition period corresponding to either Layers $5 b$ or 4 .

\section{Reindeer Stratum (All sections)}

Although differing slightly in their lithology, the succeeding levels of cave earth occupy much the same level at all sections across the cave and, with one exception at Section A, are therefore considered to be contemporaneous in age.

At Section C, the Reindeer Stratum proper is a redbrown, clayey, cave earth with few limestone pieces that is between 0.5 and $1 \mathrm{~m}$ in thickness (Field Layer 4a, Fig.7). It also stretches across the passage, but left of the mid-section is largely composed of many small shattered fragments and some small blocks of stalagmite that make it difficult to be certain if it is part of the same stratum, or if this particular area is part of the level below. The presence of further frostbroken material at this level would not, however, be inconsistent with the other known climatic indications.

At Section B, a cave earth occupies and entirely fills the West Passage to the roof (Figs.4 \& 6). In the southern half (left side) of the section it rests directly above the Stream Deposit and contains medium-sized limestone pieces, but in the northern half (above the Transition Zone) there is a greater profusion of bigger limestone rocks, and even one large boulder. At Section A the cave earth also lies above the Stream Deposit; however, it is divided into two slightly differing layers by an intervening remnant of a stalagmite floor (see below), with the hard earth below containing numerous angular fragments and small rocks of limestone, and that above (and of later date) being largely comprised of many small angular limestone fragments in a heavily cemented matrix. Collectively, these layers probably represent the 'cemented breccia' referred to by Beynon (1934).

Although an almost complete bear skull was recovered earlier from the cave earth at Section $A$ by A. J. Sutcliffe (BMNH) (Fig. 10), no fossil remains of large animals were noted in the upper deposits of the two sections in 1962-3. However, at Section $\mathrm{C}$ various bones of large mammals, including bear, wolf, fox, badger, bison and reindeer - this species being an important climatic indicator - as well as many smaller mammals, such as mole, wild cat, hare, pika, lemmings and various voles, occurred within this stratum. There were also remains of birds, amphibians, reptiles, fish and snails. A number of the larger bones of bear, bison and reindeer at Section C, together with indeterminate fragments of ribs, were found in close proximity to one another with some inclined at an angle, as if they had been 'thrown together' or had slid together down a slope (Fig.9). A broken bison metapodial exhibits signs of splintering on its front face, while naturally shed antlers of small reindeers are broken across suggesting that these breakages took place before fossilisation (Fig.10).It seems more likely that the breakages might be the result of natural processes (e.g. a fall ?) rather than being attributable to the handiwork of man. 


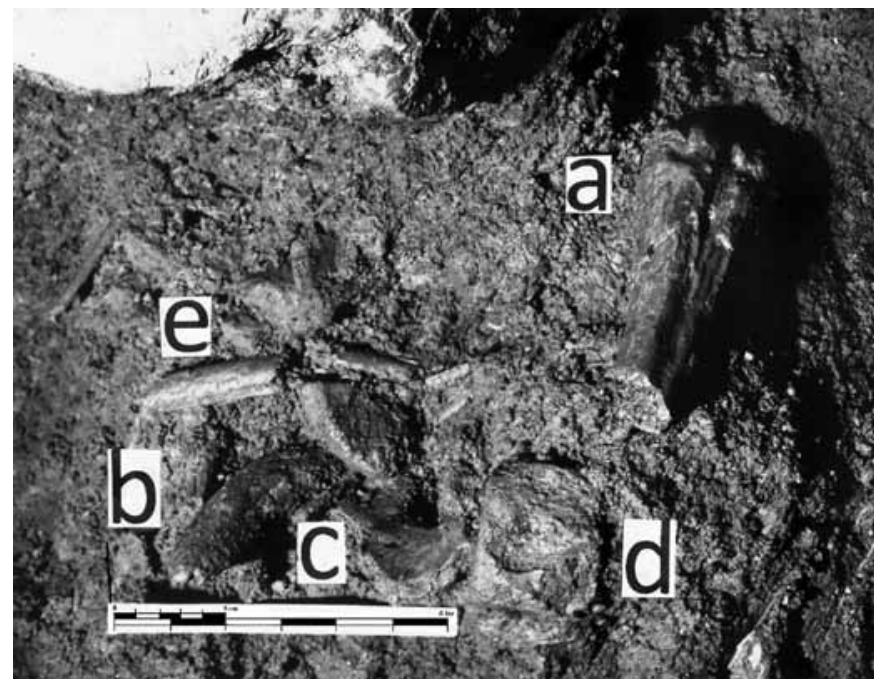

Fig. 9. Angled bones in situ in the Reindeer Stratum - Bison metapodial and horn-core tip (a-b); Reindeer pelvis (c); Bear vertebra (d); Indeterminate rib fragments (e).
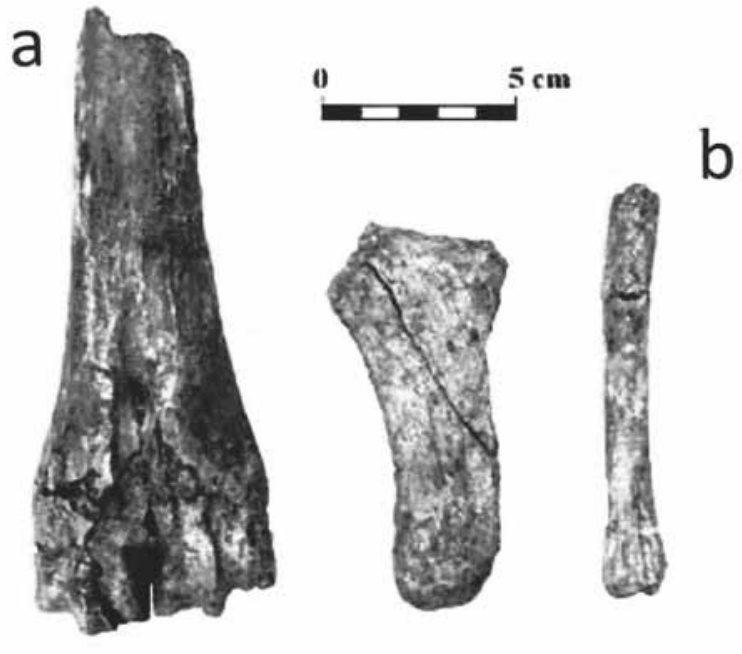

Fig. 10. Broken Bison metapodial with splintered front face (a) and broken Reindeer antler bases, including a 1st.year antler of juvenile (b) from the Reindeer Stratum (BMNH Collection).

\section{Stalagmite Floors (Sections C \& A)}

Field Layer 3, at Section C, is composed of two sectors of stalagmite (Field Layer 3a-b), occupying the same position in the deposits, i.e., they rest upon Layer 4 below, as does the remnant stalagmite floor which occurs at Section A (3c), documented below. The latter, however, is absent from Section B. These are all now considered contemporaneous in time and represent a temperate, more humid, period within the sequence.

\section{Stalagmite Floor 3a-b (Section C)}

A fairly thick stalagmite (Field Layer 3a) tightly follows the inclined roof upwards to the south, into the joint-plane, leaving little space between it and the roof, indicating it was deposited upon a talus slope (from a suspected higher passage or entrance). It sealed Layer 4 below, and prevented any further sedimentation in that particular area. Another short remnant of similar stalagmite (3b) occurs immediately below a suspended limestone rock in the mid-section and is considered to be of the same age. It is assumed that any westward extension of these stalagmites was removed during the 1927-1934 excavations.

\section{Stalagmite Floor 3c (Section A)}

The remnant floor at Section A largely consists of a round, concave, flowstone near the top of the section from under which the original infill had earlier been removed. This stalagmite is joined to the buttress but is only indicated further north (to the right) across the section by a whitish 'line' (Fig.5). A cemented zone exists at the top of Layer 4 beneath the stalagmite and below the buttress. The probable source of the flowstone was from above the buttress and it indicates a marked climatic break and hiatus in earth deposition in this sector. This floor is likely that which formerly extended across the main passage, also sealing over the remnant breccias found against the east wall, and which ran 'round to the back of the cave' as was suggested by Beynon (1934, p.129). However, no evidence of this stalagmite was seen within the strata at Section B, but it might have been originally present above the roof of the West Passage before removal at the time of quarrying.

\section{Upper Breccia Zone (Section A only)}

Above Stalagmite Floor 3c and reaching the localised roof, there is a small layer of cave earth adhering to the wall, only $1.5 \mathrm{~m}$ long, that forms a cemented breccia horizon with many small angular limestone pieces suggesting a period of continued frost action (Figs.4-5). It seems probable that this zone may have been confined only to part of the main passage in the vicinity of the buttress since it is not represented in either Sections B or C. No fossil remains were noted in this level.

\section{Thin Stalagmite Floor (Section C only)}

The next layer in the sequence at Section $C$ (Field Layer $2 \mathrm{~b}$ ) is a very thin flowstone left of $3 \mathrm{~b}$ ) that also forms a division between Layers 4 and 2. It is inclined upwards and coalesces with the later stalagmite floor (Field Layer 1) further back into the section, thereby sandwiching Layer $2 \mathrm{a}$ in between. The inclination also suggests deposition upon a talus slope. Although occupying the same position as $3 a-b$, it is considered that this floor is of a later date.

\section{Frog Stratum (Section C only)}

Field Layer $2 a$ is a dark greenish earthy deposit that is present only to the left of the suspended limestone rock. It reaches a thickness of only $15 \mathrm{~cm}$, must formerly have extended across to the roof of the cave, but pinches out behind the plane of the section after $30 \mathrm{~cm}$ due to the inclined stalagmite floor below meeting up with the next stalagmite floor above. An abundance of amphibian (frog/toad) remains, some of legless lizard, birds and snails, as well as mole, shrews and voles were recovered. Some isolated specimens of bear and reindeer also occurred but, by the reddish matrix attached, were clearly derived from Layer 4 below. In the absence of these two species, and any 
others characteristic of the Pleistocene, the stratum is considered to be of post-Pleistocene date.

\section{Stalagmite Floor (Section C only)}

The final deposit at Section C (Field Layer 1) is another thin stalagmite floor with a small $10 \mathrm{~cm}$ space between it and the cave roof. It stretches over the Frog Stratum from the central limestone rock to join the cave roof and is slightly inclined upward behind the plane of the section. The cave was then evidently again sealed in this area from any further deposition. (Note: In 2006, Layers 1 and 2a-b were no longer apparent having evidently been removed by further digging - Lundberg, et al., 2008)

\section{Recent Earths}

Two occurrences of more recent post-Pleistocene earths have been recorded in the cave that accumulated at slightly different periods of time:

\section{Badger Tunnels}

Cross-sections of badger burrows were encountered at Section A, within the Stream Deposit beneath the overhanging buttress, and at Section $\mathrm{C}$ within the blocks forming the Broken Stalagmite Floor Facies (Figs.4 \& 7). These are filled with a recent greenish earth similar to that of the Frog Stratum. It is possible that they represent remnants of the same burrow that was tunnelled through the Pleistocene sediments along the length of the cave and, if not recognised as such during the 1927-1934 excavations, could have introduced more recent elements into the fossil collection. In addition to those of badger themselves, bones recovered from the burrows were of amphibians and domestic animals (rabbit, sheep/goat). All are clearly of Recent origin and, since the burrows must have pre-dated the subsequent removal of much of the Pleistocene sediments, these can be considered Holocene, but earlier than the next layer of earth accumulation.

\section{Beynon's Limestone Soil}

At the commencement of the 1927 excavations, a Limestone Soil was recorded as covering the rock entrance vestibule to a depth of $60 \mathrm{~cm}$ and extended to the back of the cave where it was $15-30 \mathrm{~cm}$ in depth (Beynon, 1934, p. 129). This contained much vegetable matter and bones of domestic animals and birds, as well as a coin from the reign of William and Mary, and was clearly accumulated in Recent times. The soil was evidently entirely removed. The rare coin has provided a probable date for the soil and quarrying activities at the cave (see below).

\section{RESULTS 2 - THE PALAEONTOLOGY}

The Torquay Museum Collection (TMC) from Cow Cave is composed of just over 1,000 fossil and recent mammal and bird specimens, with a few human bones and some flint artefacts. For this study the collection was divided into those that had a 'fresh' appearance and were undoubtedly of Recent age, with the remains of domestic animals being predominant, those with some mineralisation that could be considered as sub-fossil, and those with heavy mineralisation that were clearly fossil remains and were largely typified by extinct or non-extant species.

Domestic species make up the bulk of the Recent bones with those of sheep and/or goat predominating, and rabbit, ox, pig, dog, cat and horse?, in diminishing order of abundance. Wild species include badger, fox, hedgehog, hare, and possibly red and roe deer.

Of particular note within the sub-fossil category, characterised by a black mottled appearance, is the presence of two left human clavicles from different individuals that have since been radiocarbon dated as 4,905 and 4,967 \pm 32 rcybp and assigned to the Neolithic Period (Oxford Radio Carbon Accelerator, Nos. OxA -17307 $\&$ 17308).

No less than $80 \%$ of the animal specimens were identified as being fossil, representing 22 animal types, of which two are totally extinct species, nine species that no longer survive in Great Britain, and several that are no longer present in Devon. The fossil remains were reported to have been 'most numerous on the left or western side, and in the upper rather than the lower levels in both the cemented and un-cemented deposits' (Beynon, 1934, p.129). These were further examined to determine, if possible, from which of the identified strata the specimens may have originated based upon attached matrix and other characteristics. For example, bones with an adhering matrix containing slate pieces derived from the Haldon Hills gravels, or rolled specimens, could indicate derivation from the Stream Deposit. In this respect, the examination was only partially successful since much of the matrix had earlier been removed, but it seems likely that the majority probably originated from the Layer 4 levels, the Reindeer Stratum.

Study of the larger mammals species was undertaken by the writer, with the smaller species (Rodents) and other groups (Birds, Amphibians, Reptiles, Fish and Molluscs) being identified by various specialists.

The species obtained from the identified strata during the 1962-3 re-investigation, preserved in the British Museum of Natural History (BMNH), are provided in table form (Tables 1\&3) and the results of the study on the Torquay Museum Collection (TMC) are also given (Tables 2-4). Full lists of all species and skeletal parts are housed in both institutions.

\section{Mammals}

The fossil mammals are here described using selected groupings that reflect the relative abundance of the identified species within the two collections.

\section{Carnivores}

No less than $80 \%$ of the entire fossil mammal collections from the cave are of carnivores representing 10 identifiable species. These predatory animals may have been responsible for the introduction of some of the other mammal remains.

Bones of the European bear, Ursus arctos, dominate the entire mammal fauna and include several restored skulls (Fig.11), upper and lower jaw bones, many teeth and a variety of skeletal parts, largely from numerous adult animals. Bones of a small number of 


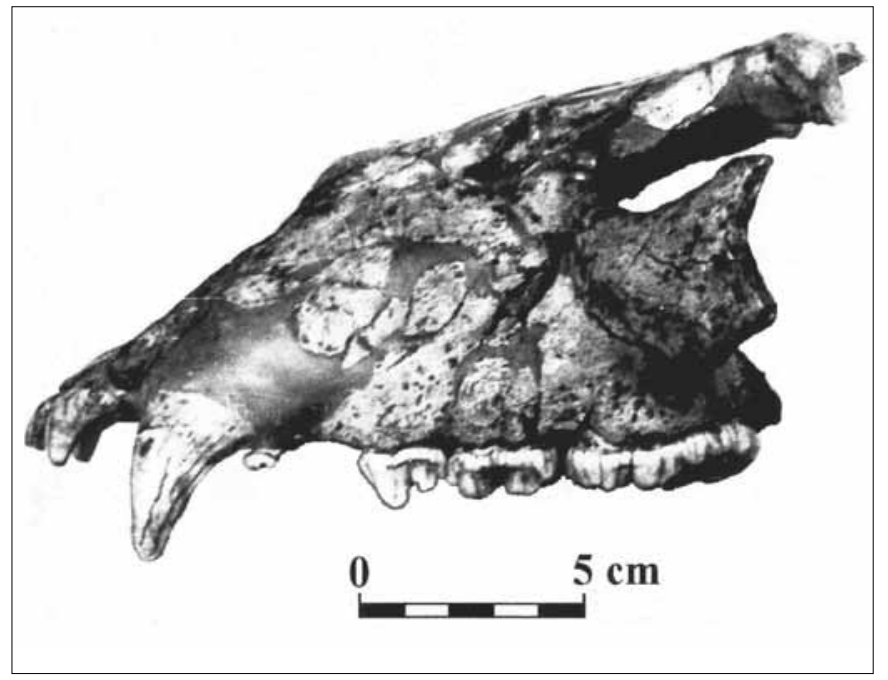

Fig. 11. Restored skull of Brown Bear from Section A (BMNH Collection).

juvenile animals are also present. Remains recovered in 1962-3 came from Layers 6 and 4 and the cave was evidently used as a den during at least one, if not both, periods.

Wolf, and then fox (Fig. 12H), are the next most abundant of the carnivores. Both are represented by adult specimens, there being no juvenile remains to suggest that these animals utilised the cave other than as casual visitors, competition with the bear perhaps being a prime factor. Both species were present in Layers 6 and 4.

Remains of a cave hyena (Fig.12E) are the next most numerous, closely followed by those of badger (Fig. 12G). The bones of hyena (all TMC) include a rear part of a skull, a lower jaw, isolated teeth, limb and foot bones, with a few specimens from juvenile animals suggesting that they may also have utilised the cave as a temporary den. No hyena bones were, unfortunately, recovered in 1962-3 to assign the species to a definitive layer, but preservation of those in TMC suggest possible derivation from both Layers 6 and 4. Badger remains were, however, only recovered from Layer 4 and one stalagmite-coated specimen in the TMC also suggests this as a possible horizon.

Bones of four of the remaining species of carnivore, lynx, polecat, lion and otter (TMC), are represented by only a few specimens. Lynx is now essentially a northern forest-dwelling species but recent evidence suggests that it may have survived in Britain to medieval times (Hetherington, et.al., 2005), whereas the polecat still survives in Wales. No strata could be assigned to these two species, but in the case of one rolled toe bone of cave lion (Fig.12B), and perhaps a humerus of otter (Fig. 12C), however, a Stream Deposit origin seems likely.

Finally, there are several jaws that are clearly from wild cat that were initially categorised as sub-fossil (TMC) (Fig. 12F). Since a single specimen, probably of this species, was recovered from Layer $4(\mathrm{BMNH})$ it is possible that these may also be fossilised, although wild cat is also known from Holocene deposits and the species still survives in mountainous areas of Scotland.

\section{Deer \& Bison}

Specimens of up to three species of deer and a bison amount to $9 \%$ of the combined TM and BMNH collections.

Reindeer remains are the most numerous in this grouping, and comprise a stalagmite-coated rear of skull, with the stalagmite containing amphibian bones (TMC), a number of antler bases the majority of which have been naturally shed (TMC \& BMNH), broken fragments of antler beams, some teeth, and a variety of skeletal parts. The small sizes of most of the remains, together with some isolated limbbone epiphyses indicate that they are from female or juvenile animals.

Remains of red deer, Cervus elaphus, include a jaw, teeth and some limb, foot and toe-bones. No specimens of this species were, regrettably, recovered from the identified levels in 1962-3, but preservation (TMC) suggests derivation from Layer 4 and perhaps Layer 6. Several, seemingly fossil, bones of roe deer could not be assigned to any stratum.

This writer noted no specimens of the giant, or "Irish Deer", Megaceros giganteous, in TMC as given in Beynon's list.

The BMNH collection includes horn-core tips and metapodials of a small bison, comparable to the European bison, Bison bonasus, while the TMC has also some teeth, broken fragments of metacarpals, foot and toe-bones of this species.

Remains of both the bison and reindeer (Fig.10) were almost exclusively found in Layer 4 at Section C, none being recovered from Layer 6 . From the evidence obtained and preservation of the specimens, it is likely that all of the TMC bison and reindeer bones also originated from Layer 4.

\section{Hares and Rodents}

Hares, of three species, and rodents of up to ten species, jointly make up an additional $9 \%$ of the mammal collections.

An undetermined hare, Lepus sp., was obtained from both Layers 6 and 4 and two humerii of large size (TMC), of unknown stratum, could be of the snow hare, Lepus cf. variabilis. Stalagmite coated remains of a single animal of this species was also recovered from a 'rock fissure' at Chudleigh in 1939 (TMC). A single jaw and tooth of pika, or Tailess Hare, Ochotona pusilla, was also obtained from Layer 4.

A few isolated rodent specimens, mainly lower jaws (stratum unknown), were present in TMC, but the majority were obtained in 1962-3 from sieving of the two principal fossil deposits, so their stratigraphical positions are known. The rodent fauna includes several identifiable species of lemming that were obtained from both Layers 6 and 4, while the majority of the various types of voles, that include three species extinct in Great Britain, and a field mouse, were all recovered from Layer 4. However, numerous rodent specimens sieved from Layer 6 have yet to be identified.

Of particular note (TMC) is a lower jaw of a beaver (Castor fiber), that still has the Haldon slate matrix attached showing it was derived from the Stream Deposit (Fig.12D). 
Table 1. List of species and specimens from strata identified during the 1962-3 re-investigation [British Museum (Nat.Hist.) Collection]

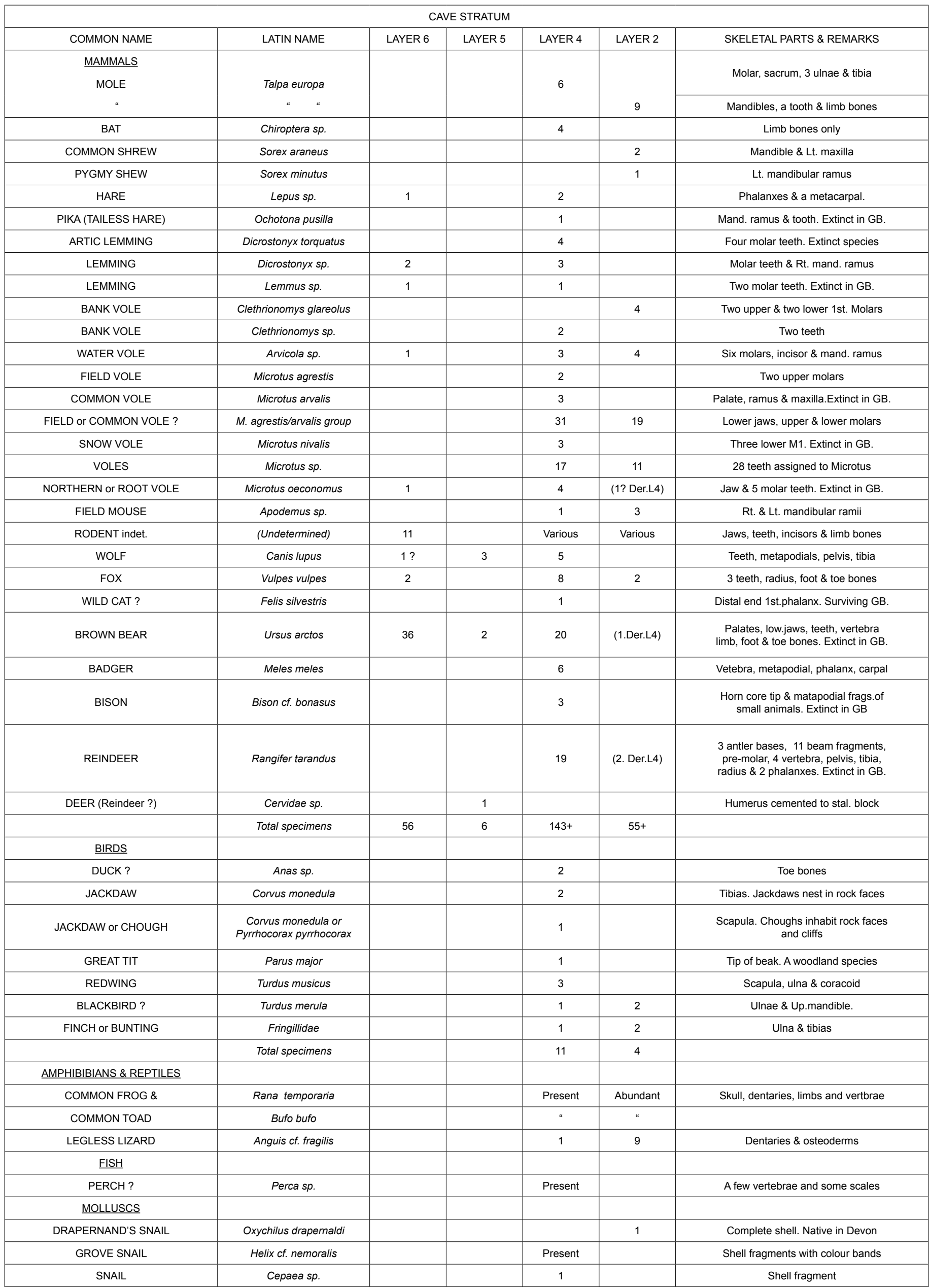


Table 2. List of species and specimens, by preservation, from the 1927-1934 excavations [Torquay Museum Collection].

\begin{tabular}{|c|c|c|c|c|c|}
\hline COMMON NAME & LATIN NAME & FOSSIL & SUB-FOSSIL & RECENT & SKELETAL PARTS \& REMARKS \\
\hline \multicolumn{6}{|l|}{$\underline{\text { MAMMALS }}$} \\
\hline HEDGEHOG & Erinaceaous europaeus & & & 7 & Lower jaws \& articulating limb bones \\
\hline HARE & Lepus sp. & 12 & 1 & 3 & Mostly limb bones (x1 ex Layer 4 ?) \\
\hline SNOW HARE? & Lepus variabilis? & 2 & & & Lt. \& Rt. Humerii. Extinct in GB. \\
\hline RABBIT & Orytolagus cuniculus & & & 30 & Jaws, vertebrae, limb, foot \& toe bones \\
\hline LEMMING & Dicrostonyx sp. & 2 & & & Low.jaw \& palate fragment. Extinct in GB. \\
\hline WATER VOLE & Arvicola sp. & 1 & & & Lower jar (prob.ex Layer 4) \\
\hline FIELD or COMMON VOLE? & M. agrestis/arvalis group & $2 ?$ & & & Left \& Right lower jaws \\
\hline NORTHERN or ROOT VOLE & Microtus oeconomus & 1 & & & Right lower jaw. Extinct in GB. \\
\hline BEAVER & Castor $s p$. & 1 & & & Low.jaw. L.6 matrix attatched. Extinct in GB. \\
\hline RODENT indet. & (Undetermined) & 4 & & & One cheek tooth \& three incisors \\
\hline WOLF & Canis lupus & 65 & & & $\begin{array}{l}\text { Maxilla, jaws, teeth, vertebrae, limb \& foot } \\
\text { bones. No apparent juveniles. Extinct in GB. }\end{array}$ \\
\hline DOG & Canis familiaris & & & 4 & Tooth, pelvis, femur \& phalanx \\
\hline FOX & Vulpes vulpes & 44 & 3 & 9 & $\begin{array}{l}\text { Teeth, low.jaws, vertebrae, pelvis, fore \& } \\
\text { hind limb bones, foot \& toe bones. Almost } \\
\text { entirely adult specimens. }\end{array}$ \\
\hline HYENA & Crocuta crocuta & 24 & & & $\begin{array}{l}\text { Skull rear, low.jaw, teeth, limb \& foot bones, } \\
\text { Only } 3 \text { juvenile specimens. Some bones } \\
\text { suggest Layers } 6 \text { \& } 4 \text { origins. Extinct in GB. }\end{array}$ \\
\hline LYNX & Felis lynx & 1 & & & Left 2nd.metatarsal. Extinct in GB. \\
\hline LION & Panthera spelea & 3 & & & $\begin{array}{l}\text { Two phalanges \& large canine root (? Lion). } \\
\text { Rolled phalanx suggests derivation Layer } 6 . \\
\text { Extinct species }\end{array}$ \\
\hline CAT & Felis catus & & & 3 & Three foot bones \\
\hline WILD CAT? & Felis silvestris & & 3 & & Two Rt.Low.jaws/ Lt. ulna. Survives in Scotland \\
\hline BROWN BEAR & Ursus arctos & 528 & & & $\begin{array}{l}\text { A restored skull, maxilla, lower jaws, pre } \\
\text { molars } \& \text { canine teeth, vertebrae, pelves, } \\
\text { sternum bone, ribs, fore \& hind limb bones, } \\
\text { foot } \& \text { toe bones. Juvenile specimens are } \\
\text { present. Extinct in GB.(by } 10 \text { th.Century) }\end{array}$ \\
\hline BADGER & Meles meles & $8 ?$ & & 22 & $\begin{array}{l}\text { Jaws, teeth, vertebrae, pelvis, sacrum, fore } \\
\& \text { hind limb bones. Sacrum coated with stal. }\end{array}$ \\
\hline POLECAT & Mustela cf. putorius & 1 & & & Proximal end Rt. Femur. Survives in Wales. \\
\hline OTTER & Lutra sp. & 4 & & & Canine, Lt. humerus \& radius, 1st. Phalanx \\
\hline HORSE & Equus cf.ferrus & 7 & & $1 ?$ & Incisors, cheek teeth, Lt. scaphoid \& atlas \\
\hline WOOLLY RHINOCEROS & Coelodonta antiquitatis & 3 & & & $\begin{array}{l}\text { Up.milk tooth, Rt. Pm2, cheek tooth frag. } \\
\text { Extinct species }\end{array}$ \\
\hline PIG & Sus scrpfa & & 1 & 5 & Rt.humerus, lower jaws \& teeth, phalanges \\
\hline BISON & Bison cf. bonasus & 15 & & & $\begin{array}{l}\text { Teeth, metacarpal frags., foot } \& \text { toe bones } \\
\text { Extinct in GB. }\end{array}$ \\
\hline DOMESTIC OX & Bos taurus & & & 7 & Milk tooth, low.molars, femurs \& phalanges \\
\hline REINDEER & Rangifer tarandus & 25 & & & $\begin{array}{l}\text { Skull rear (stal. coated), antler bases and } \\
\text { fragments, } 2 \text { teeth, scapula, humerus, } \\
\text { epiphyses of radii \& femur (juveniles), foot } \\
\text { and toe bones. Probably all L.4. Extinct in GB. }\end{array}$ \\
\hline RED DEER & Cervus elaphus & 22 & & 3 & $\begin{array}{l}\text { Jaw, teeth, humerus, scapula, metacarpals, } \\
\text { foot \& toe bones. Layers } 6 ? \& 4 \text { preservation }\end{array}$ \\
\hline ROE DEER & Capreolus capreolus & $3 ?$ & & 2 & Phalanxes \& metatarsal. Scapula \& thoracic \\
\hline DEER sp. & Cervidae & 8 & & & Tooth frags., humerus, metatarsals, phalanxes \\
\hline \multirow[t]{2}{*}{ SHEEP \&/OR GOAT } & \multirow[t]{2}{*}{ Ovicapridae } & & 7 & & Tibias, metacarpals \& tarsals. Black mottled \\
\hline & & & & 53 & $\begin{array}{l}\text { Jaws, teeth, vertebrae, pelvis, sacrum, } \\
\text { scapula, fore \& hind limb bones, foot \& toe } \\
\text { bones }\end{array}$ \\
\hline \multirow[t]{4}{*}{ MAN } & \multirow[t]{3}{*}{ Homo sapiens } & & 4 & & Premolar, phalanx \& clavicles- black mottled \\
\hline & & & & 3 & 2 thoracic vertebrae \& 1 calcaneum \\
\hline & & 9 & & & $\begin{array}{c}9 \text { flint flakes }-x 2 \text { identified as Levalloisian \& } \\
\text { x1 as Creswellian }\end{array}$ \\
\hline & Total specimens & 795 & 19 & 152 & \\
\hline
\end{tabular}


Table 3 - Combined list of fossil mammal species, by known and assumed strata, within both TM and BMNH collections

\begin{tabular}{|c|c|c|c|c|c|c|c|}
\hline \multirow{2}{*}{\multicolumn{2}{|c|}{$\begin{array}{c}\text { COMBINED MAMMAL SPECIES IN THE } \\
\text { THE TORQUAY MUSEUM AND BMNH. COLLECTIONS } \\
(\mathrm{X} ?=\mathrm{TM} \text {.Colln - possible stratum derivation })\end{array}$}} & \multicolumn{4}{|c|}{ PLEISTOCENE STRATUM } & \multirow{3}{*}{$\begin{array}{c}\text { GROUPINGS } \\
\% \text { OF } \\
\text { TOTAL } \\
\text { COLLNS. }\end{array}$} & \multirow{3}{*}{ REMARKS } \\
\hline & & \multirow{2}{*}{$\begin{array}{l}\text { STREAM } \\
\text { DEPOSIT } \\
\text { LAYER } 6\end{array}$} & \multirow{2}{*}{$\begin{array}{l}\text { BROKEN } \\
\text { STAL. FLOOR } \\
\text { LAYER } 5\end{array}$} & \multirow{2}{*}{$\begin{array}{l}\text { REINDEER } \\
\text { STRATUM } \\
\text { LAYER } 4\end{array}$} & \multirow{2}{*}{$\begin{array}{l}\text { UNDETERMINED } \\
\text { LAYER/S } \\
\text { (TM.Colln.) }\end{array}$} & & \\
\hline COMMON NAME & LATIN NAME & & & & & & \\
\hline MOLE & Talpa europa & & & $x$ & & \multirow{2}{*}{$1 \%$} & \\
\hline \multirow[t]{2}{*}{ BAT } & Chiroptera sp. & & & $x$ & & & No diagnostic bones \\
\hline & & & & & & $X X X X X X X$ & \\
\hline HARE & Lepus sp. & $x$ & & $x$ & & \multirow{3}{*}{$2 \%$} & \\
\hline SNOW HARE? & Lepus variabilis? & & & & $x$ & & Artic hare. Extinct in G.B. \\
\hline \multirow[t]{2}{*}{ PIKA (TAILESS HARE) } & Ochotona pusilla & & & $x$ & & & A steppe species. Extinct in G.B. \\
\hline & & & & & & $x x x x x x x$ & \\
\hline ARTIC LEMMING & Dicrostonyx torquatus & & & $x$ & & \multirow{13}{*}{$7 \%$} & ) \\
\hline LEMMING & Dicrostonyx sp. & $x$ & & $x$ & $x$ & & ) All tundra/steppe species. Extinct in G.B. \\
\hline LEMMING & Lemmus sp. & $\mathrm{x}$ & & $x$ & & & ) \\
\hline BANK VOLE & Clethrionomys sp. & & & $\mathrm{x}$ & & & \\
\hline WATER VOLE & Arvicola sp. & $x$ & & $x$ & $\mathrm{x}$ & & \\
\hline FIELD VOLE & Microtus agrestis & & & $x$ & & & \\
\hline COMMON VOLE & Microtus arvalis & & & $x$ & & & Extinct in G.B. \\
\hline FIELD or COMMON VOLE & M. arvalis/agrestis group & & & $x$ & $x$ & & \\
\hline SNOW VOLE & Microtus nivalis & & & $x$ & & & An alpine vole. Extinct in G.B. \\
\hline VOLES & Microtus sp. & & & $x$ & & & \\
\hline NORTHERN or ROOT VOLE & Microtus oeconomus & $x$ & & $\mathrm{x}$ & $x$ & & Extinct in G.B. \\
\hline FIELD MOUSE & Apodemus sp. & & & $x$ & & & \\
\hline \multirow[t]{2}{*}{ BEAVER } & Castor sp. & $\mathrm{X}$ ? & & & & & A forest \& riverine species. Extinct in G.B. \\
\hline & & & & & & $X X X X X X X$ & \\
\hline WOLF & Canis lupus & $x$ & $x$ & $x$ & $x$ & \multirow{10}{*}{$80 \%$} & Extinct in G.B. but survived until c. $1500-1700$ \\
\hline FOX & Vulpes vulpes & $\mathrm{x}$ & & $x$ & $x$ & & \\
\hline HYENA & Crocuta crocuta & $\mathrm{X}$ ? & & $\mathrm{X} ?$ & $x$ & & Extinct in G.B. \\
\hline LYNX & Felis lynx? & & & & $x$ & & Extinct in G.B. Prefers woodlands \& caves \\
\hline LION & Panthera spelea & $\mathrm{X}$ ? & & & $x$ & & Extinct cave species. \\
\hline WILD CAT? & Felis sylvestris? & & & $x$ & $x$ & & Present in mountainous areas of Scotland \\
\hline BROWN BEAR & Ursus arctos & $x$ & $x$ & $x$ & $x$ & & Extinct in G.B. May have survived to 10 th.C. \\
\hline BADGER & Meles meles & & & $x$ & $x$ & & \\
\hline POLECAT & Mustela cf.putorius & & & & $\mathrm{x}$ & & Species surviving in Wales \\
\hline \multirow[t]{2}{*}{ OTTER } & Lutra sp. & $\mathrm{X}$ ? & & & $x$ & & Possibly a fossil form now extinct in G.B. \\
\hline & & & & & & $X X X X X X X$ & \\
\hline HORSE & Equus cf. ferrus & & & & $x$ & \multirow{2}{*}{$1 \%$} & \\
\hline \multirow[t]{2}{*}{ WOLLY RHINOCEROS } & Coelodonta antiquitatis & $\mathrm{X}$ ? & & & $x$ & & A steppe/tundra, totally extinct species \\
\hline & & & & & & $x X X X X X X$ & \\
\hline BISON & Bison cf. bonasus & & & $x$ & $x$ & \multirow{4}{*}{$9 \%$} & Extinct in G.B. Relict in Poland \\
\hline REINDEER & Rangifer tarandus & & $\mathrm{X}$ ? & $x$ & & & A steppe/tundra species. Extinct in G.B \\
\hline RED DEER & Cervus elaphus & $\mathrm{X} ?$ & & $\mathrm{X} ?$ & $x$ & & A woodland species \\
\hline ROE DEER ? (Fossil ?) & Capreolus capreolus & & & & $x$ & & \\
\hline
\end{tabular}

Table 4. combined list of the bird species identified in the tm and bmnh collections

\begin{tabular}{|c|c|c|c|c|c|c|c|}
\hline \multirow{2}{*}{\multicolumn{2}{|c|}{ BIRD SPECIES $(4 ?=$ No. of specimens $)$}} & \multirow{2}{*}{\multicolumn{2}{|c|}{ TORQUAY MUSEUM COLLN. }} & \multicolumn{3}{|c|}{ BRITISH MUSEUM (NAT. HIST.) COLLN. } & \multirow{2}{*}{ SKELETAL PARTS \& REMARKS } \\
\hline & & & & \multirow{2}{*}{$\begin{array}{l}\text { REINBEER } \\
\text { STRATUM }\end{array}$} & & & \\
\hline COMMON NAME & LATIN NAME & FOSSIL & RECENT & & $\begin{array}{c}\text { FROG } \\
\text { STRATUM }\end{array}$ & UNSTRATIFIED & \\
\hline MALLARD & Anas plaryrhynchos & $4 ?$ & & & & & Coracoids, radius \& scapula \\
\hline TEAL ? & Anas crecca & 1 & & & & & Coracoid \\
\hline GOOSANDER & Mergus merganser & 1 & & & & & Coracoid \\
\hline SHELDUCK & Tadorna tadorna & 3 & & & & & Humerus, ulna, tarso-metatarsus \\
\hline GOOSE (cf. GREY LAG GOOSE) & Anser anser & 1 & & & & & Coracoid \\
\hline DUCK Sp. & Anas sp. & 2 & & 2 & & & Sternum frag.,radius (Large size), toe bones (RS) \\
\hline DOMESTIC DUCK & Anas sp. & & 3 & & & & Metacarpals, tarso-metatarsus \\
\hline EAGLE (cf.GOLDEN EAGLE) & Aquila chrysactos & 1 & & & & & Hind claw \\
\hline
\end{tabular}




\begin{tabular}{|c|c|c|c|c|c|c|c|}
\hline COMMON BUZZARD & Buteo buteo & 2 & & & & & Tibias \\
\hline KESTREL & Falco tinnunculus & & $1 ?$ & & & & Tarso-metatarsus \\
\hline BLACK GROUSE & Lyrurus tetrix & & 1 & & & & Femur \\
\hline GROUSE (cf.WILLOW GROUSE) & Lagopus lagopus & $8+4 ?$ & & & & & Ulnas, humerus, tibio-tarsi, t-metatarsus \\
\hline PTARMIGAN & Lagopus mutus & 5 & & & & & Tarso-metatarsus ( $\times 4$ ? Ptarmigan) \\
\hline REDSHANK? & Tringa totanus & $1 ?$ & & & & & Tibio-tarsus \\
\hline STOCK or ROCK DOVE & Columba oenus or C.livia & & $2 ?$ & & & & Ulan, coracoid \\
\hline BARN OWL & Tyto alba & & 1 & & & & Metacarpal \\
\hline SKYLARK & Alauda arvensis & & 1 & & & & Ulna \\
\hline CARRION CROW & Corvus corone & 1 & & & & & Coracoid \\
\hline JACKDAW & Corvus monedula & & 20 & 2 & & & Various Recent \& 2 fossil tibias (R.Stratum) \\
\hline CHOUGH (cf. RED-BILLED) & Pyrrhocorax pyrrhocorax & & 1 & & & & Ulna \\
\hline JACKDAW or $\mathrm{CHOUGH}$ & Corvus or Pyrrhocorax & & & 1 & & & Fossil scapula \\
\hline JAY? & Garrulus glandarius & 1 & & & & & Coracoid \\
\hline GREAT TIT & Parus major & & & 1 & & & Tip of beak \\
\hline MISSEL THRUSH ? & Turdus viscivorous & & 1 & & & & Ulna \\
\hline SONG THRUSH & Turdus ericetorum & & 6 & & & $1 ?$ & Humeri, ulnas, femur, tibia \\
\hline RED WING & Turdus musicus & & 34 & $3 ?$ & & 1 & A variety of bones \\
\hline RED WING or THRUSH & Turdus sp. & & & & & 1 & Not specified \\
\hline BLACKBIRD & Turdus merula & $1 ?$ & 7 & 1 & $2 ?$ & $2 ?$ & Humeri, ulnas, tibias, coracoid? fossil, Up.mandible \\
\hline PIPPIT (cf. MEADOW PIPIT) & Anthus pratensis & & 3 & & & & Humerus, ulna, tarso-metatarsus \\
\hline FINCH or BUNTING & Fringilled sp. & & & 1 & 2 & & Ulna, tibias \\
\hline DOMESTIC FOWL & Gallus $s p$ & & 2 & & & & Femurs (1 juvenile) \\
\hline \multirow[t]{2}{*}{ BIRD Indet. } & Aves sp. & 5 & & & & & Not determined \\
\hline & Total specimens & 41 & 83 & 11 & 4 & 5 & \\
\hline
\end{tabular}

\section{Mole, Bat, Rhinoceros \& Horse}

A small number of specimens make up the remaining $2 \%$ of the mammal collections. Limb bones of an undetermined bat and various bones of mole (Talpa europa) were obtained only from Layer 4 (BMNH), while several teeth of Woolly Rhinoceros (Coelodonta antiquitatis) are present (TMC), one of which has a 'polished' appearance and suggests a Stream Deposit (Layer 6) origin (Fig.12A), and some teeth of a fossil horse (Equus $c f$. ferrus) for which no stratum could be reliably assigned.

\section{Birds}

The bird remains were the subject of a separate specialist report (Bramwell, 1963, unpublished). In summary, the 1962-3 BMNH collection contains a small number of stratified specimens of a limited number of species of variable habitat recovered from only Layers 4 and 2 (Tables $1 \& 4$ ), whereas there were over 120 specimens of birds within TMC, one third of which were considered to be un-stratified fossils representing 14 identifiable species, the remainder being of recent preservation and presumably originated from Beynon's Limestone Soil (Table 4). Climatically important, and representing the most abundant of the fossil species, are the willow grouse form and ptarmigan that both favour cold moorland habitats, the latter now only found in the highlands of Scotland. Also of interest is the presence of the possible golden eagle, extinct south of Scotland, and the buzzard both of which use cave and cliff nesting sites. Such predatory birds would likely have introduced remains of their prey into the cave, such as hares, rodents, and other bird species such as the ptarmigan.

\section{Amphibians, Reptiles, Fish \& Snails}

Dentaries and bones of amphibians and reptiles were recovered from sieved material in 1962-3 from both layers 4 and 2, being particularly abundant in the latter. Fish vertebrae and scales were obtained only from Layer 4, while shells of snails, some retaining their colour bands, were found in both levels (BMNH), pointing to free-flowing water and damp conditions (Table1).

\section{Flint Artefacts}

Of the eight flint artefacts (TMC), one is a small backed-blade now assigned to the Creswellian industry, a style which occurs only within Upper Pleistocene stages, notably the Last Glacial period. Such artefacts have been recovered in greater numbers from the nearby Pixie's Hole (Colcutt, 1984) and indicate a level of Devensian age. The presence of only a single specimen from Cow Cave suggests that there was either no significant stratum of that date within the cave, the cave did not present a suitable habitat for Man's long-term utilisation, or the specimen was derived from elsewhere.

Some of the remaining flakes are considered to date from the "early upper Palaeolithic" (Campbell, 1977) and several have been assigned to the Levalloisian technique (R.Clarke - personal communication). One of these is slightly rolled suggestive of carriage within a stream (i.e., the Stream Deposit), whereas the other is in a 'mint-condition' (Fig. 13). The single flake, also possibly of Levallois type, unequivocally obtained from Layer 6 (BMNH), suggests that the others may have also been derived from this stratum. 


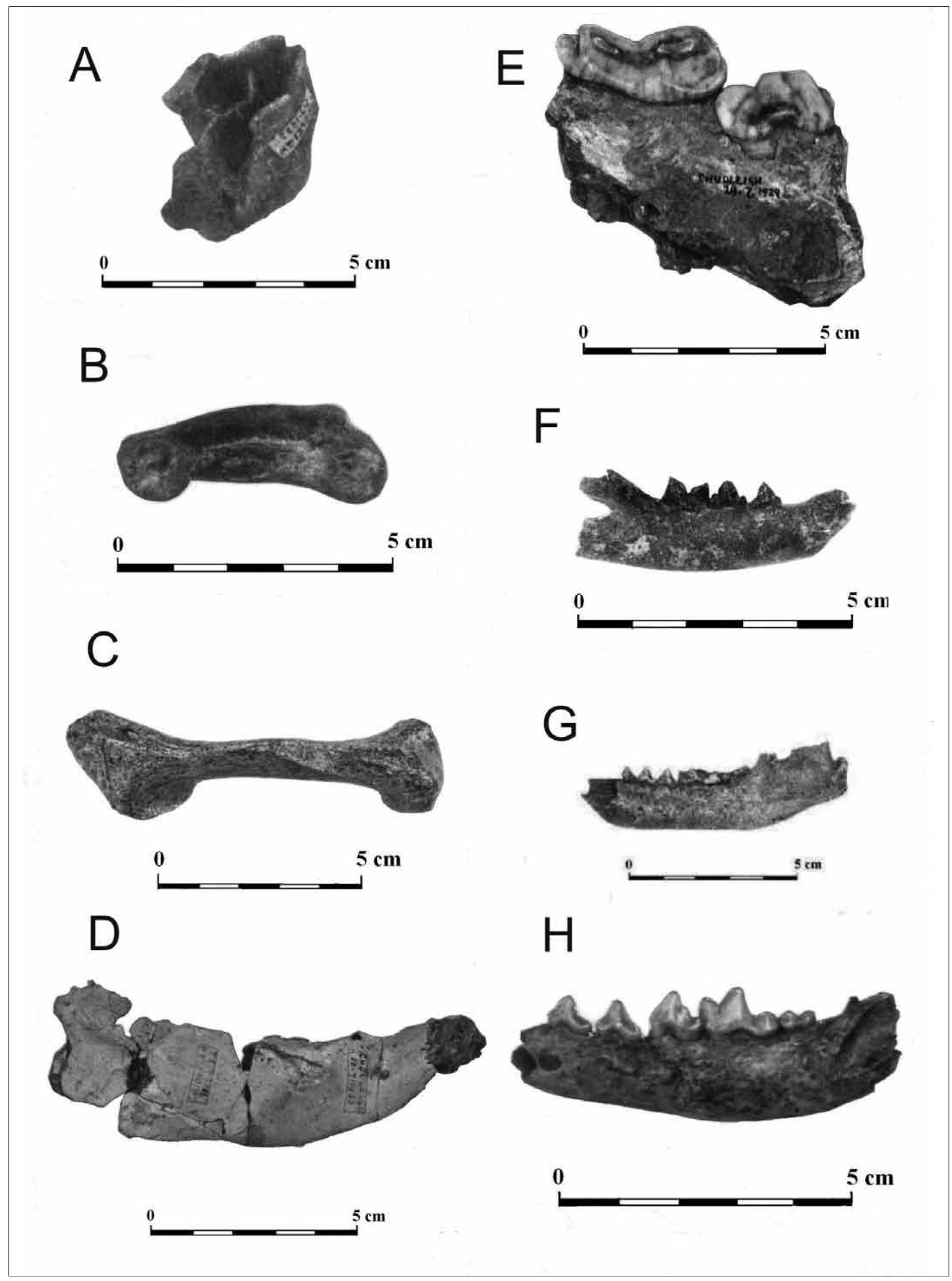

Fig.12. Various fossil mammal remains in the Torquay Museum Collection. A. Premolar tooth of juvenile Woolly Rhinoceros -? from the Stream Deposit. B. Toe bone of Cave Lion - ? from the Stream Deposit. C. Humerus of Otter - ? from the Stream Deposit. D. Lower jaw of Beaver from the Stream Deposit. E. Part lower jaw of Cave Hyena. F. Lower jaw of Wild Cat. G. Lower jaw of Badger. H. Lower jaw of Fox. 


\section{DISCUSSION}

The results of this re-investigation, and of the absolute dating reported in Lundberg et al. (2008), give rise to several hypotheses about early quarrying, former cave entrances, modes of sedimentation, and climatic implications of the sediments and the fauna.

\section{Quarrying Activities}

Although quarrying of the limestone had long been in operation at Chudleigh, it was earlier thought that none had occurred at Cow Cave (Beynon, 1934, p.129). This writer contends, however, that the cave entrance has been greatly altered and much of the interior deposits were removed at that time. At the entrance, the west wall is very much broken into blocks, and the unnatural flat rock floor and raised platform, are all suggestive of quarrying. A 'drill-hole' is also visible in the cliff face west of the cave. Simon Colcutt has also concluded that the cave entrance has been radically modified and a test pit in the old spoil at the edge of the former cliff, outside of the cave, also showed $2 \mathrm{~m}$ of spoil overlying 'quarry debris' (Colcutt, 1984, p. 886). This could explain why the cave entrance area and part of the interior floor was found in 1927 to be composed of a 'limestone soil' containing recent animal bones as well as the coin from the reign of William and Mary. Also, there were apparently no earlier sediments that would have been expected to accumulate on a platform outside of a natural entrance.

The rare coin provides a possible time period for the soil as well as a probable date for quarrying activities at the cave. King William III, a Prince of Orange in Holland, married Mary and became King of Great Britain and Ireland from 1688 to his death in 1702 . His reign was therefore rather short and was followed in quick succession by the reigns of Queen Anne and George I, from 1702 to 1727 . George II then had a longer reign (1727-1760) and was followed by George III who reigned for 60 years. Given that any coins minted during the reign of William and Mary may have remained in circulation, say for another 70 years

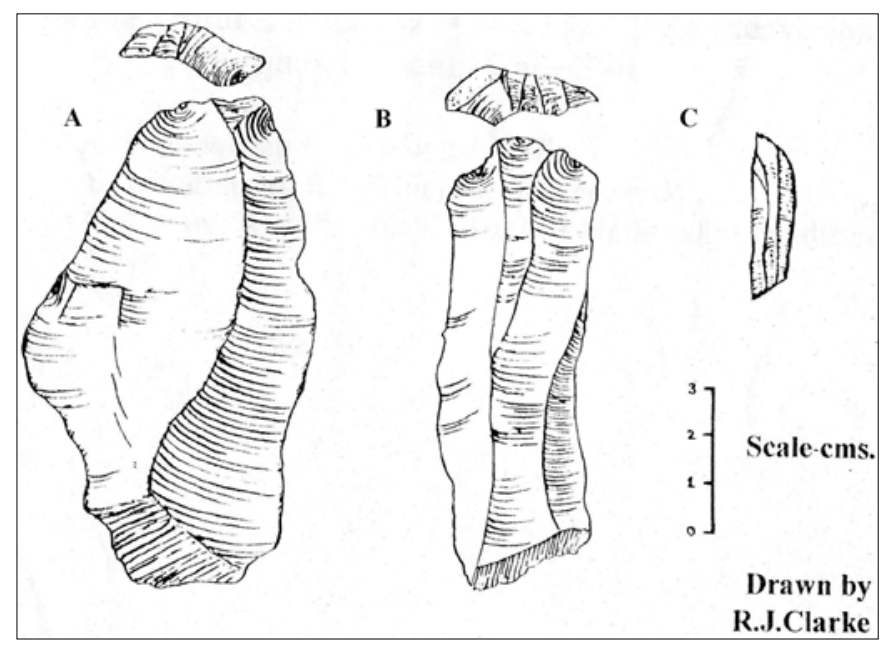

Fig.13. Some artefacts from Cow Cave, 1927-1934 excavations [Torquay Museum Collection]. A. Levalloisian flake (slightly rolled); B. Levalloisian flake (almost mint condition); C. Creswellian [“Azilian”] backed blade (mint condition). before being replaced, then the coin could have been deposited in the cave at anytime between 1700 and 1760 , the latter being around the time when bones were being recovered from fissures in other limestone quarries (Polwhele, 1797).

\section{Cave entrances, sediment deposition \& climatic interpretations}

Interpretation of the available evidence suggests that there were a number of former entrances into the cave during several climatic periods that would have influenced the process of sedimentation and account for the difference in lithology of the strata within.

The basal Stream Deposit, with its cold/temperate faunal elements, obviously originated from higher up the gorge and invaded the pre-existing phreatic cave system that comprised Pixie's Hole and Cow Cave, the surface of the deposit being at much the same heights within these cave passages. The Kate Brook stream was then of sufficient force to carry and deposit heavy loads of stones and gravel into the cave as a result of seasonal melt-waters from snow-covered areas, such as upon the higher Haldon Hills. The high level of the stream within the gorge points to the cave stratum being of some antiquity.

At Section A the Stream Deposit significantly reaches to the underside of the over-hanging buttress, extends outwards and in-fills the channel between the west wall, the rock platform and the rock floor forming the present entrance vestibule. This suggests that the early stream once occupied a former 'exit' passage beneath the overhang, and the buttress may originally have extended further across the cave to form a barrier that was subsequently removed by quarrying, hence the rock floor and platform. During the Pleistocene, there would then have been lower and upper portals opening into the cave from the gorge (See Figs. 4 \& 14).

Upon the sealing of the lower passage with stream gravels, the later sediments could then only accumulate behind the rock barrier suggesting that these materials, and possibly the animal remains, probably originated from another entry rather than from the less accessible upper entrance portal that would have been at least $3.5 \mathrm{~m}$ higher, and probably a great deal more, in the original cliff face.

An end to the period of materials carried in by flood melt-waters, together with valley down-cutting, subsequently caused a cessation of stream flow into the cave. This was followed by a long temperate period represented by the deposition of the stalagmite floor at Section C (5a). This thick stalagmite floor may largely have accumulated beneath the joint-plane above the eastern passage where an open fissure would have allowed more precipitation, and not on the western side towards which the floor must evidently have petered out. A narrow fissure that prevented easy ingress, or a temporary sealing of the passage further on by growth of the floor, could also account for the notable absence of any other corresponding deposits and fauna.

This warm period was followed by an intensely cold 
interlude marking the onset of more arctic conditions as evidenced by the later upheaval and shattering of the stalagmite floor, during or following which sediment filled the spaces between the blocks and were perhaps also carried west down the passage to Section B (The Transition Zone).

It has been assumed that the cave-earth deposits on the west side of the cave are part of the same Layer 4 (Reindeer Stratum) as at Section C. Here, however, the talus matrix is more clayey with some shattered stalagmite fragments, but fewer limestone pieces than across the cave where angular pieces and rocks of limestone as a result of frost action are more abundant. These differences may possibly be explained by freeze/thaw solifluction upon a slope from the eastern side-entrance that carried the frost broken materials deeper into the cave. The area of large rocks and a boulder in the north upper corner at Section B further suggests their carriage in a mud flow. However, the existence of yet another unknown entrance deeper within the West Passage, from which this might also have originated, cannot entirely be ruled out. These all suggest very cold conditions during the accumulation of the stratum, a conclusion that is fully supported by the fauna.

At Section C, several of the later stalagmite floors, sediments, and even bones in Layer 4, suggest deposition upon a talus slope beneath a higher, but then more open, entrance rift or connecting cave.

It appears likely that the nearby earth-filled fissure and Chudleigh Rift represent entrances into an upper passage level beyond the sediment infill, which is 6-7 $\mathrm{m}$ below, from which materials would have been able to enter into the East-West Passage and fill the body of the cave behind the rock barrier.

The inclined stalagmite floors above Layer 4 (3ab) at Section C, were deposited during a later, contemporaneous, temperate period and would probably have extended further as floors along the East-West Passage. It is also now believed that the flowstone remnant within the cave-earths at Section A (3c), which it is assumed formed the noted floor across the main passage from the barrier buttress, similarly sealed Layer 4 beneath. If correct then another and much later level, during which frost action reoccurred, was then deposited above this floor. This Upper Breccia Zone would then represent a stage that preceded The Frog Stratum (Layer 2). Since it was not represented at either Sections C or B, where by then the cave was already largely filled, its materials might have accumulated via the upper entrance passage above the barrier and the stratum may not therefore have extended throughout the cave.

The very thin stalagmite floor at Section $C(2 b)$, that forms the division between Layers $4 \mathrm{a}$ and $2 \mathrm{a}$, may have been deposited at a time when some disturbance of the underlying layer occurred in that sector and resulted in a few specimens of Pleistocene species being introduced into the level above, and possibly visa-versa.

The Frog Stratum (Field Layer 2a) at Section C was clearly deposited during a temperate period at the humid base of a talus slope where some ingress was still possible from the easterly entrance. The final stalagmite floor (Layer 1), also indicating temperate conditions, sealed the cave from any further sedimentation in this sector. It seems unlikely that any of the Layers 1-2 strata would have extended far along the passage.

Based upon the above evidence and theories, a hypothetical correlation of the strata of the sections across the cave is now tentatively presented as a basis for future research and discussion (Fig.14).

\section{The faunas $\&$ their climatic indications}

As a result of the study of the remains housed in the two museums and assuming that certain species in TMC are correctly assigned to the identified strata, then the faunal assemblages for the principal Pleistocene levels would appear to be as provided in Table 5 . These, together with the acquired stratigraphical data, enable further inferences to be drawn as to the climatic conditions prevailing at the time of deposition of the various layers.

The positive presence of lemmings and the assumed Woolly Rhinoceros, indicate that the basal stream level in the cave was deposited during a cold period when the nearby surroundings, such as Dartmoor, may have been within a boreal zone. Some animal remains would certainly have been carried into the cave by the stream (e.g. rhinoceros teeth/lion toebone), but drier spells as in winter may have permitted various species, such as bear and hyena, and possibly Palaeolithic man, to enter the cave. The undoubted presence of beaver, and possibly red deer, suggest a more wooded environment. A substantial tree cover, together with free-flowing water, would have been a necessity for both beaver and otter and the more sheltered valley and gorge of the early Kate Brook may have fulfilled these conditions. This suggests that the remains were derived from varied habitats that occurred in the region at the time and that the climate may have been somewhat more temperate than a fully glacial stage.

During the later Reindeer Stratum, the presence of a nearby steppe or tundra environment is collectively supported by the fauna that includes reindeer, bison, pika, lemming, arctic and northern voles.

Reindeer are a noted migratory, steppe or tundra, species that shed their antlers at specific times of the year. Of the total antler bases in the collections, five had been naturally shed and one of these is a $1^{\text {st }}$ year antler from a juvenile. Only two antler bases were not naturally shed. All are of small size and likely represent female and juvenile animals. It has been earlier demonstrated that studies of shed antler bases, as at Banwell and Tornewton Caves, can provide insight into when the animals may have migrated into an area during Pleistocene times since the two sexes do not shed their antlers at the same time of the year (Sutcliffe, 1955; Sutcliffe \& Zeuner, 1962). Using this criterion suggests that the reindeer at Cow Cave were absent during the winter in Devon, the period being too severe, but would have migrated 


\section{COW CAVE, CHUDLEIGH, DEVON}

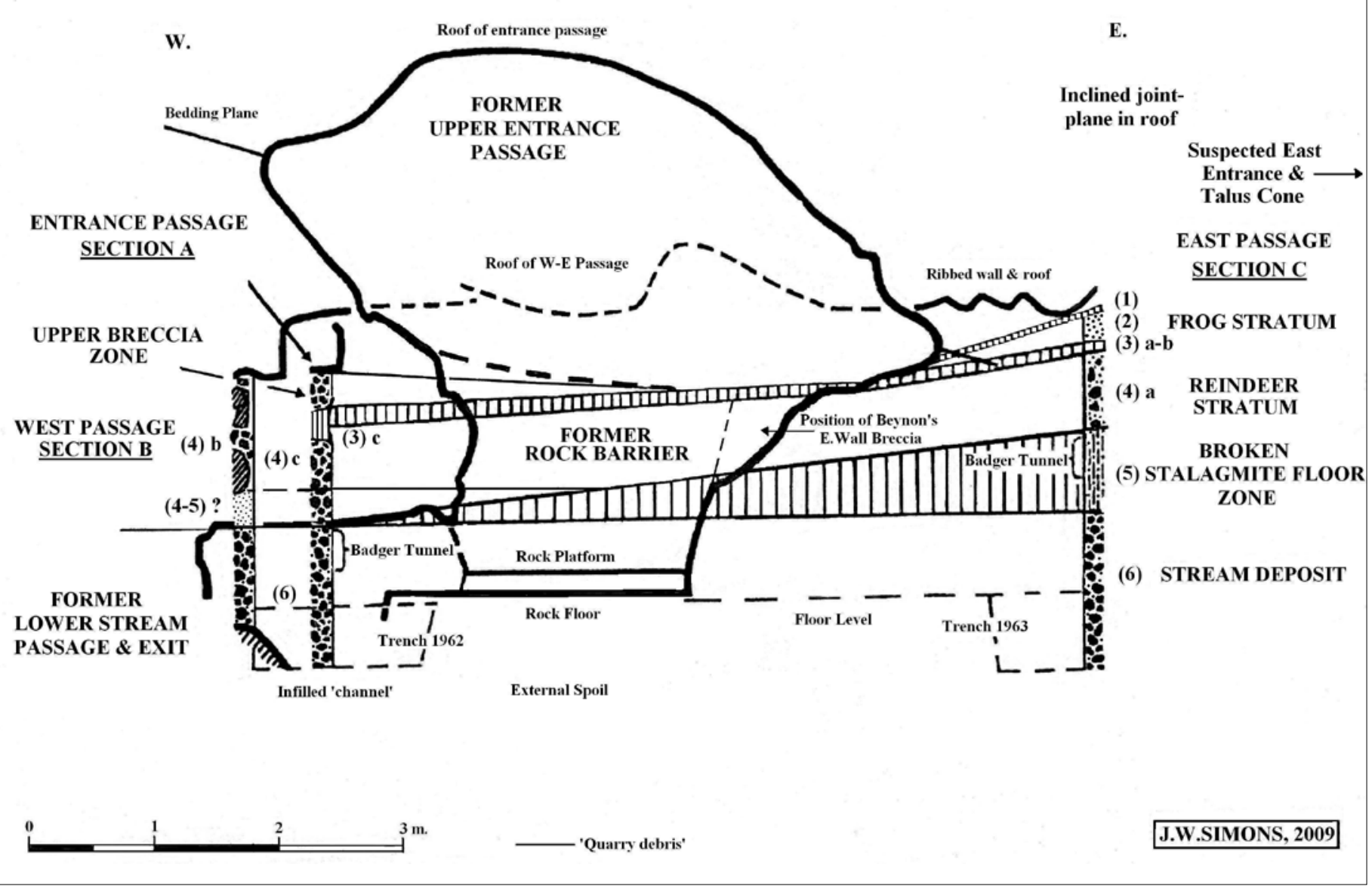

Fig.14. Cross-section of main Entrance Passage, with assumed former entrances and rock barrier, showing the relative positions of the sections together with a hypothetical interpretation of the strata across the cave.

into the area from the continent during the spring and summer months. The presence of a $1^{\text {st }}$ year antler, which would have been shed at this time, supports the conclusion.

Bison is also considered a migratory species and the small size of the bones of some individuals suggest they may also be from female or juvenile animals that could have travelled along with the reindeer. To account for the presence in the cave of female and juvenile animals of these two species, one must assume that they were brought in by carnivores, or perhaps by man ?, employing selective hunting techniques.

It is the remains of the following small mammals, all of which are extinct in Great Britain, that provide further evidence of a cold climate and the possible age of the stratum. These are: pika, or Tailess Hare (Ochotona pusilla), and lemmings (Lemmus sp.) that include a totally extinct form of arctic lemming (Dicrostonyx torquatus). Among the voles, the common vole (Microtus arvalis), northern or root vole ( $M$. oeconomus) and snow vole ( $M$. nivalis), are also boreal species extinct in Great Britain. Several of these species were also recovered from Kennard's earlier shelter or fissure excavation (Hinton, 1926). Bank and water voles are normally associated with open- water environments. The presence of snow vole in the collection has, however, been questioned (see below).

The amphibian and reptile remains, particularly abundant in the Frog Stratum (Layer 2a), and snail shells, all point to damp and temperate conditions at the time of accumulation of that deposit, e.g. in the vicinity of, or at the base of an entrance fissure or tunnel. In addition to both common frogs and toads, a specimen has been further identified as Natterjack Toad, Bufo calamita (Holman, 1988), upon which there has been a radiocarbon date discussed below.

\section{Absolute and relative dating}

Samples from the stalagmite making up Layer 5 have been analysed and a chronology for the strata, fauna and 'Middle Palaeolithic' artefacts in the cave been published (Lundberg, et. al., 2008). The analyses provided dates of $167 \pm 2 \mathrm{ka}$ for the original stalagmite floor (Sample 2b- Stalagmite 1) and $148 \pm 1 \mathrm{ka}$ for a broken block (Sample 3c - Broken Stalagmite Floor Facies). These dates are crucial to relative dating of the other strata. Basically, the conclusions reached at that time, with some additional notes and discussion, are shown as follows under stages of events within the cave:

Stage I. Stream Deposit (Layer 6) 
Table 5 - Summary of the strata, sedimentation history, fauna and climatic indications within Cow Cave by event stages, together with MIS and relative dating

\begin{tabular}{|c|c|c|c|c|c|c|c|c|}
\hline \multirow{2}{*}{$\begin{array}{l}\text { EVENT } \\
\text { STAGE }\end{array}$} & \multirow{2}{*}{$\begin{array}{l}\text { FIELD } \\
\text { LAYER }\end{array}$} & \multirow{2}{*}{$\begin{array}{l}\text { CAVE DEPOSIT } \\
\text { NAME }\end{array}$} & \multirow{2}{*}{ SEDIMENT TYPES } & \multirow{2}{*}{$\begin{array}{c}\text { ENTRANCES \& SEDIMENTATION } \\
\text { HISTORY }\end{array}$} & \multicolumn{2}{|r|}{ FAUNA } & \multirow{2}{*}{$\begin{array}{l}\text { ASSUMED } \\
\text { CLIMATE }\end{array}$} & \multirow{2}{*}{$\begin{array}{l}\text { MIS \& RELATIVE } \\
\text { DATING }\end{array}$} \\
\hline & & & & & MAN & OTHER SPECIES & & \\
\hline$(X b)$ & & $\begin{array}{l}\text { Recent Earth } \\
\text { (Ex Beynon, 1934) }\end{array}$ & $\begin{array}{l}\text { Limestone soil \& vegetable } \\
\text { matter forming new cave } \\
\text { floor in and outside cave }\end{array}$ & $\begin{array}{l}\text { Up. \& Low. entrance area quarried } \\
\text { creating single entrance. Much of } \\
\text { Pleistocene deposits removed. Cave } \\
\text { used from mid-1700's \& soil deposited }\end{array}$ & Pesent & $\begin{array}{l}\text { Hedgehog, hare, fox, badger, } \\
\text { red deer \& roe deer? Domestic } \\
\text { species: rabbit, dog, cat, horse?, } \\
\text { pig, ox, sheep/goat. Birds. }\end{array}$ & As today & Present Day \\
\hline IX a) & & $\begin{array}{l}\frac{\text { Recent Earth }}{\text { Badger Tunnels }} \\
\text { B. }\end{array}$ & $\begin{array}{l}\text { Dark greenish earth } \\
\text { (Similar to Frog Stratum) }\end{array}$ & $\begin{array}{l}\text { Depositied prior to Stage IX b and } \\
\text { later removal of Pleistocene deposits. }\end{array}$ & Present? & $\begin{array}{l}\text { Badger, domestic sheep/goat. } \\
\text { Amphibians \& Birds }\end{array}$ & Temperate & $\begin{array}{c}\text { Holocene } \\
\text { (Neolithic time ??) }\end{array}$ \\
\hline VIII & 1 & $\underset{\text { (Section C only) }}{\text { Stalagmite } 4}$ & Thin stalagmite floor & $\begin{array}{l}\text { Deposited on talus slope. Seals Frog } \\
\text { Stratum and closes cave at Section C }\end{array}$ & & & Temperate & Holocene \\
\hline \multirow{2}{*}{ VII } & $2 a$ & $\begin{array}{l}\text { Frog Stratum } \\
\text { (Section C only) }\end{array}$ & Dark greenish earth & $\begin{array}{l}\text { Deposited on talus slope with possible } \\
\text { opening above/beyond Section C. } \\
\text { Limited extension west down passage? }\end{array}$ & & $\begin{array}{l}\text { Mole, shrews, voles, mouse, } \\
\text { fox, birds, abundant frog/toad, slow } \\
\text { worm \& molluscs }\end{array}$ & $\begin{array}{l}\text { Temperate } \\
\text { (wet/humid) }\end{array}$ & \multirow{2}{*}{ Flandrian Intergalcial } \\
\hline & $2 \mathrm{~b}$ & $\frac{\text { Stalagmite 3(Section }}{\underline{\text { c only) }}}$ & $\begin{array}{l}\text { Thin stalagmite floor } \\
\text { (Between Layers } 4 \text { \& 2) }\end{array}$ & $\begin{array}{l}\text { Deposited on talus slope, then disturbed } \\
\& \text { fossil species introduced into Layer } 2\end{array}$ & & & Temperate & \\
\hline $\mathrm{VI}$ & & $\frac{\text { Upper Breccia Zone }}{\text { (Section A only) }}$ & $\begin{array}{l}\text { Thin layer of cemented earth } \\
\& \text { small (frost-fractured) } \\
\text { limestone fragments. }\end{array}$ & $\begin{array}{l}\text { Probable origin from main Upper } \\
\text { Entrance. May have extended further on } \\
\text { top of Layer 3c, across \& into cave ? }\end{array}$ & $\begin{array}{l}\text { Level of } \\
\text { Creswellian } \\
\text { blade ?? }\end{array}$ & Unknown & Cold & $\begin{array}{l}\text { Earlier than L. } 2 \\
\text { \& later than L.4. } \\
\text { (Devensian ??) }\end{array}$ \\
\hline \multirow{2}{*}{ v } & \multirow{2}{*}{3} & \multirow{2}{*}{$\begin{array}{l}\text { Stalagmite 2 } \\
\text { All assumed to be } \\
\text { contemporaneous } \\
\text { c) absent at Section B }\end{array}$} & $\begin{array}{l}\text { a-b) Thickish stalagmites } \\
\text { (Sectn.C) }\end{array}$ & $\begin{array}{l}\text { Deposited on slope. Seals Layer } 4 \\
\text { and closes east rift entrance }\end{array}$ & & & \multirow{2}{*}{ Temperate } & \multirow{2}{*}{$\begin{array}{l}\text { Presumed } \\
\text { MIS } 5 \\
\text { (Ipswhichian } \\
\text { Intergalacial) }\end{array}$} \\
\hline & & & $\begin{array}{l}\text { c) Concave flowstone } \\
\text { (Sectn. } \\
\text { A) dividing cave earths. }\end{array}$ & $\begin{array}{l}\text { Flowstone floor. Probably originally } \\
\text { extending across the main passage }\end{array}$ & & & & \\
\hline \multirow{3}{*}{ IV } & \multirow{3}{*}{4} & $\frac{\text { Reindeer Stratum }}{\text { (Section C) }}$ & $\begin{array}{l}\text { a) Red-brown clayey earth } \\
\text { with stal.fragments but few } \\
\text { limestone rocks. Filling } 5 \mathrm{~b}\end{array}$ & $\begin{array}{l}\text { Originating from an open east rift } \\
\text { entrance. Angled bones of large animals } \\
\text { suggest accumulation on a talus slope. }\end{array}$ & $?$ & \multirow{3}{*}{$\begin{array}{l}\text { Mole, bat, hare, pika, lemmings } \\
\text { \& voles (extinct in G.B.), mouse, } \\
\text { wolf, fox, wild cat, brown bear, } \\
\text { badger, bison \& reindeer. Hyena } \\
\text { \& red deer ? Also birds, frog/ } \\
\text { toad, legless lizard, fish \& snails }\end{array}$} & \multirow{3}{*}{$\begin{array}{l}\text { Steppe or } \\
\text { Tundra } \\
\text { (Warmer } \\
\text { than event } \\
\text { Stage III ?) }\end{array}$} & \multirow{3}{*}{$\begin{array}{c}\text { Interstadial } \\
\text { or full Glacial } \\
\text { phase within MIS } 6 \\
\text { (Wolstonian Glacial) } \\
\text { [Equivalent to } \\
\text { 'Glutton Stratum' of } \\
\text { Tornewton Cave ?] }\end{array}$} \\
\hline & & (Section B) & $\begin{array}{l}\text { b) Hard brown earth with } \\
\text { angular limestone rocks \& } \\
\text { boulders in part }\end{array}$ & $\begin{array}{l}\text { Solifluction mud flow (from east rift ?) } \\
\text { carrying larger rocks, filling main body } \\
\text { of cave \& West Passage to the roof }\end{array}$ & & & & \\
\hline & & (Section A) & $\begin{array}{l}\text { c) Hard brown earth with } \\
\text { angular limestone rocks }\end{array}$ & $\begin{array}{l}\text { Freeze-thaw mud flow from east rift } \\
\text { filling the cave behind the rock barrier }\end{array}$ & & & & \\
\hline III or IV & $4-5 ?$ & $\frac{\text { Transition Zone ? }}{\text { (Section B only) }}$ & $\begin{array}{l}\text { Cave earth relatively free } \\
\text { of limestone pieces with } \\
\text { ? whitish indications of stal. }\end{array}$ & $\begin{array}{l}\text { Solifluction sediment from } \\
\text { ? east rift deposited during Stage III or } \\
\text { later as part of Stage IV. }\end{array}$ & & Unknown & Cold & $\begin{array}{l}\text { As above or } \\
\text { below }\end{array}$ \\
\hline III & $5 b$ & $\frac{\text { Broken Stalagmite }}{\text { Floor Facies }}$ & $\begin{array}{l}\text { Blocks \& angular pieces of } \\
\text { stalagmite with } L 4 \text { cave earth } \\
\text { filling the interstitial spaces }\end{array}$ & $\begin{array}{l}\text { Shattering \& up-heaval of Stalagmite } \\
\text { Floor } 3 \text { by intense frost action. Opening } \\
\text { of eastern entrance through rifting? }\end{array}$ & & $\begin{array}{l}\text { Wolf, brown bear, reindeer? } \\
\text { (Derived from Layer } 4 \text { ?) }\end{array}$ & $\begin{array}{l}\text { Glacial } \\
\text { Steppe or } \\
\text { Tundra }\end{array}$ & $\begin{array}{c}\text { Full glacial } \\
\text { MIS Stage } 6 \\
\text { (Wolstonian Glacial) }\end{array}$ \\
\hline$\|$ & $5 a$ & $\frac{\text { Stalagmite } 1}{\text { (Section C only) }}$ & $\begin{array}{l}\text { Original thick layer of } \\
\text { crystalline stalagmite in } \\
\text { East-West Passage }\end{array}$ & $\begin{array}{l}\text { Deposition on top of L.6 at Section C } \\
\text { but petering-out westward along } \\
\text { the cave. Hiatus in other sediment } \\
\text { deposition through cave entrances }\end{array}$ & & & $\begin{array}{l}\text { Temperate } \\
\text { (Warmer } \\
\text { than L.6 } \\
\text { \& L.4) }\end{array}$ & $\begin{array}{l}\text { Stalagmite dates } \\
148 \& 167 \text { (ka) } \\
\text { Interstadial of MlI } 6 \\
\text { (Wolstonian Glacial) }\end{array}$ \\
\hline \multirow[t]{3}{*}{1} & 6 & $\frac{\text { Stream Deposit }}{\text { (All sections) }}$ & $\begin{array}{l}\text { Flint pebbles \& other rocks } \\
\text { derived from the Eocene } \\
\text { gravels higher up the Kate } \\
\text { Brook valley at Great Haldon }\end{array}$ & $\begin{array}{l}\text { Cave opened through valley down- } \\
\text { cutting and invasion by the early } \\
\text { Kate Brook stream at high level }(+25 \mathrm{~m} \text {.) } \\
\text { in the gorge \& filling lower passage. }\end{array}$ & $\begin{array}{l}\text { Present } \\
\text { Levalloisian } \\
\text { artifacts }\end{array}$ & $\begin{array}{l}\text { Hare, lemmings, vole, wolf, fox, } \\
\text { brown bear, beaver \& possibly } \\
\text { hyena, cave lion, otter, woolly } \\
\text { rhinoceros \& red deer. }\end{array}$ & $\begin{array}{l}\text { Cold - } \\
\text { Temperate } \\
\text { (Warmer } \\
\text { than L.4) }\end{array}$ & $\begin{array}{l}\text { Cold period of MIS } 7 \\
\text { (Averley Interglacial) } \\
\text { or early MIS } 6 \\
\text { Glacial }\end{array}$ \\
\hline & & & $\begin{array}{l}\text { No early sediments reached } \\
\text { in cave excavation }\end{array}$ & $\begin{array}{l}\text { Faulting of limestone, draining of the } \\
\text { phreatic cave \& valley down-cutting }\end{array}$ & & & & Pre-Pleistocene \\
\hline & & & & $\begin{array}{l}\text { Phreatic cave (Pixie's Hole/Cow Cave) } \\
\text { formed in the Devonian Limestone }\end{array}$ & & & & Post-Devonian \\
\hline
\end{tabular}

The stream gravels, fauna and 'Levalloisian' artefacts of Stage I within the cave obviously predate the original Stalagmite Floor 1. The suggestion is, therefore, that this stratum is of MIS 7 age, the Averley Interglacial, but represents a colder phase following the interglacial maximum. It could also be an early phase of MIS 6. The admixture of cold and more temperate elements in the fauna, with a specific absence of Reindeer, tends to indicate that conditions were, however, warmer than occurred in the later Layer 4 stratum.

\section{Stage II - Stalagmite Floor 1(Layer 5a)}

The dated stalagmite samples from within the Broken Stalagmite Floor Zone probably represent an Interstadial phase of the MIS 6 Glacial. Basically, the two dates provide some indications of the period of growth of the original crystalline floor of Stalagmite I (i.e. between 167-148 ka) that occurred during a long temperate interlude that was warmer than Stages I \& IV.

This hiatus was at a time when the cave was not receiving any other noted sediment deposition or animals from external sources and the East-West Passage was presumably not directly open to the surface.

Stage III - Broken Stalagmite Floor Facies (Layer 5b)

The younger of the dated samples was collected from a broken block higher within the BSF zone and the break-up of the original Stalagmite Floor I must have taken place following this date. It is, therefore, suggested that the fracturing and upheaval of the floor was effected during the glacial maximum of MIS 6, the Wolstonian, at around $136 \mathrm{ka}$. It clearly marks a major environmental change and the event 
is considered by the writer to represent a separate time stage during which the cave was re-opened to the surface along the East-West Passage, perhaps by joint-rifting, and further deposition was then possible within.

Stage III or IV - Transition Zone (Layer 4-5?)

It is uncertain if this horizon should be correlated with the Broken Stalagmite Floor Facies above or represents an early stage in the deposition of Layer 4 when the cave was re-opened and sediments filled the spaces created between the broken stalagmite blocks.

Stage IV. Reindeer Stratum (Layer 4a-c)

At least part of the strata divisions of the following Reindeer Stratum (4a) is believed to have originated beneath an entrance or upper level along the East Passage, forming a talus-cone, and there is currently no reason to believe that those across the cave $(4 \mathrm{~b}-$ c) are of any earlier date. There are some concerns, however, in making a correct age assignment for this stratum.

In nearby Pixie's Hole, the deposits occur at around the same altitude as those in Cow Cave and a similar, but slightly different, sequence of sediments has been identified and an upper level of Last Glacial age is clearly indicated by the presence of a 'Creswellian' industry (Colcutt, 1984), yet in Cow Cave only a single blade of unknown provenance was recovered. It might therefore, by association, be considered that this stratum should, or could, be the same as in Pixie's Hole, but access into the cave and the processes of sedimentation in widely separated passages has also to be taken into account and these might well differ over space and varying climatic periods of time. The Cow Cave passages may well have been closed off from the rest of the cave complex.

The occurrence of Microtus nivalis, a species that is considered to have been entirely absent from Devensian localities in Britain, has been suggested as indicative of a pre-Ipswichian deposit in the cave (Sutcliffe \& Kowalski, 1976). In this case, then the Reindeer Stratum would likely be of Wolstonian Glacial age. This identification has, however, been questioned on the grounds that only the third upper molar is diagnostic and this tooth was not represented in the collection (Colcutt, 1984). It does seem tenuous to base an age solely upon a few, possibly missidentified (or introduced) teeth, but the original identification was by $\mathrm{G}$. B. Corbet (BMNH) and later confirmed by K. Kowalski, noted specialists in rodent remains, and it seems unlikely that both could be wrong. If the specimens had also been derived from an earlier stratum, then the same might have to apply to the other rodent remains.

The Steppe Pika, also known from Kennard's Fissure at Chudleigh and a few other Devon caves (Happaway Cave $\&$ Broken Cavern) has also largely been associated with Late Glacial to Holocene deposits, with dates of around 11-10 ka, although some earlier Pleistocene occurrences are known (Fisher \& Yalden, 2004). It might be inferred that its presence also indicates a late date for the Reindeer Stratum, but again there is always a chance of the species having been introduced, in this case, possibly from above.

A radiocarbon date of 9,270 \pm 80 rcybp (Anon, 1988) on a sample of Natterjack Toad, Bufo calamita, apparently from Field Layer 4, introduces another element. This young date would also point to the deposit being of a late stage, i.e. at the close of or just after the Devensian. There is, however, again a distinct possibility that the specimen may be an inclusion, say from the Frog Stratum above (where the date would be much more appropriate), and the provenance must therefore be treated with caution.

To accept a Devensian age for the Reindeer Stratum cave-earths, and thereby assume a later date for the overlying Stalagmite Floor 2 (Layer 3), would mean that the Cow Cave sector of passages would have been closed since the deposition of Stalagmite 1 at MIS 7- 6, throughout the Ipswichian Interglacial (with no representation whatsoever), until the Last Glacial, a period of more than 120,000 years. This seems an inordinate period of time without any intervening periods of sedimentation within and animal utilisation of the cave.

Despite the apparent similarity of the mammal assemblage to the faunas that typify the Devensian stage, the Reindeer Stratum fauna might perhaps be correlated with a similar but early mammal assemblage, with reindeer and a small ox or bison, and Microtus nivalis, that was present in the 'Glutton Stratum' of Tornewton Cave. However, there was no hyena in that stratum and number of other species at this site (e.g. glutton) are absent at Cow Cave (Sutcliffe \& Zeuner, 1962). Recent TIMS dating of a stalagmite appears to indicate that the later 'Hyena Stratum' in Tornewton Cave, with its decidedly warm fauna of Hippopotamus, Fallow Deer and Narrow-Nose Rhinoceros, is c.134 ka years in age (Gilmour, et al., 2007), i.e. it may mark the onset of the MIS 5, Ipswhichian Interglacial maximum. It follows that the 'Glutton Stratum' is earlier, and if the Reindeer Stratum of Cow Cave is correlated with it, then it would logically be sandwiched between c.134 $147 \mathrm{ka}$ and this would seem to fit with the Cow Cave chronology as presented.

With this possible correlation in mind, and discounting the above concerns as being uncertain at this time, the conclusion is reached that the Reindeer Stratum represents deposition during a very cold, but perhaps Interstadial phase of MIS 6, the Wolstonian Glacial period.

Stage V. Stalagmite Floor 2 (Layers 3a-c)

By the time deposition of the Reindeer Stratum came to a close, the West Passage was filled to its roof and the East Passage virtually so, while the Main Passage was almost filled up against the rock barrier. Stalagmite floors then sealed the stratum, closed the eastern entrance, and covered the layer along the main body of the cave, leaving only a space above that would have corresponded with the early upper passage and its entrance in the cliff face. The various parts of Stalagmite Floor 2 represent a temperate hiatus and, in order of succession, are therefore presumed to represent a part of MIS 5, the Ipswichian Interglacial, the 'Hyena Stratum' of Tornewton Cave being absent. 


\section{Stage VI. Upper Breccia Zone (No Field Layer)}

Following stalagmite floor deposition during the preceding Stage, there was only the upper entrance passage, high in the cliff face, which remained open to the elements. It is probably from down this passage that frost-broken materials entered into the cave at the rock barrier to form the Upper Breccia Zone that seemingly did not extend throughout the cave. In the absence of the level in the East Passage sequence and, again, following the order of succession, it is possible that this stratum represents a cold phase of the otherwise missing Devensian Glacial period. It is also tempting to suggest that the single 'Creswellian' artefact could have been derived from this level.

Stage VII. Stalagmite Floor 3 \& Frog Stratum (Layer2a-b)

The Frog Stratum was deposited upon the very thin stalagmite floor remnant ( $2 \mathrm{~b})$, which is now considered to be later than the stalagmites (3a-c) of Stage $V$ and to be an early part of Stage VII. At this time, some disturbance of the underlying cave-earth occurred to introduce isolated specimens of Pleistocene species (e.g. reindeer) from below. The stratum accumulated at the base of a talus slope and it is assumed that there was again a temporary, not necessarily large, opening through the talus cone to the surface or passage beyond. A burrowing animal, such as badger, could well have created such a connection and led to disturbance. The Frog Stratum is clearly postPleistocene in date and has therefore been assigned to the Flandrian (first stage of the Holocene) Interglacial [MIS 1] that followed the Devensian. The date for the Natterjack Toad would fit well for this stratum.

Stage VIII. Stalagmite 4 (Layer 1)

A final stalagmite floor sealed the Frog Stratum and finally closed the eastern entrance from any possible further deposition into the cave in this sector. It is also considered to be Holocene, and closed the Flandrian Stage.

\section{Stage IX. Recent Soils}

The soils within the badger tunnels (IXa), with recent domestic species, are considered to be post-Frog Stratum but pre-Beynon's Limestone Soil (IXb). The majority of the remains of recent domestic animals in TMC, with some wild species, likely originated from this soil, but derivation of some from within the badger tunnels is also a possibility. It is now considered that Beynon's Limestone Soil accumulated following the quarrying of the cave entrance and the 'mining' of much of the Pleistocene deposits around the mid1700's, after which the cave was utilised by humans and domestic stock to the present day.

The radiocarbon dates of around 4,900 \pm 32 rcybp for the sub-fossil human collar bones, mentioned earlier, raise a problem in that no distinct deposit of Neolithic age was recognised anywhere in the cave. Unless the specimens were recovered from an extension of the Frog Stratum level, or even from within part of the badger tunnels, it would have to be concluded that they were derived from other soils no longer present within the known stratified sequence that were removed and unrecorded.
A summary of the principal stages of events, sedimentation history, faunas, climatic conditions and dating of the deposits is provided in Table 5.

\section{CONCLUSIONS \& RECOMMENDATIONS}

It has been demonstrated that the deposits and faunas in Cow Cave cover a time-frame from around the close of Stage 7, the Averley Interglacial, at perhaps 170,000 years ago, through to the Flandrian Interglacial and up to the present day, thus making it one of the more important palaeontological caves of Devon.

The original cave passage opening onto the gorge was enlarged through quarrying and there were formerly lower, upper and side entrances into the cave that were variously closed or opened at certain stages, influencing the processes of sedimentation within and access to animals, and perhaps humans.

The oldest Pleistocene level in the cave is a streamlaid gravel, deposited during flood-like conditions that, with its contained fauna (and probable Levallois artefacts), indicates a mixed cold-temperate period after the Interglacial maximum of MIS 7. This was followed by a series of interspersed stalagmite floors, representing temperate breaks in the accumulation of sediments from external sources, the principal one of which immediately follows the stream gravels and has been U-Th dated to 167 and $148 \mathrm{ka}$ and is considered to be an Interstadial of the MIS 6, Wolstonian Glacial. The subsequent shattering and upheaval of this floor is believed to represent the glacial maximum of the Wolstonian at around $136 \mathrm{ka}$. This was followed by cave-earths, of slightly differing lithologies, that were deposited by solifluction (freeze/thaw mud flows) to largely fill the cave passages, and likely originated from an open easterly entrance where a talus-cone is suspected. The faunal assemblage of this level, together with frost-shattered limestone rocks and fragments, indicates steppe or tundra conditions and is considered to represent a fully Glacial or Interstadial phase within the Wolstonian and may perhaps be correlated with the Glutton Stratum of Tornewton Cave. The level was then sealed by another stalagmite floor which is presumed to occupy the position of the MIS 5, Ipswichian Interglacial. The final Pleistocene level, indicative of cold conditions, occurs above this floor and is now believed to represent the otherwise 'missing' MIS 2, the Devensian Glacial. The last earth deposit, of an altogether different type and found only at the base of a talus slope within the East Passage, contained a decidedly Holocene fauna. This was then sealed by a thin stalagmite floor that closed the known stratigraphical sequence of deposits within the cave and both levels likely represent the post-Pleistocene, Flandrian Interglacial. Much more recent earths were deposited in badger tunnels and later upon the cave floor following quarrying activities in the $18^{\text {th }}$ century.

The age interpretation of the strata above Stalagmite 1, in particular the Reindeer Stratum and its associates, is still however open to debate and additional controlled excavation in the cave, further stalagmite dating, and careful collection of fauna is 
clearly needed to add to the data so far obtained.

It appears likely that further excavation into both the East and West Passages may prove instructive, in particular further eastwards into the suspected talus-cone. Similarly, digs beyond Section C, within Chudleigh Rift and the nearby earth-filled fissure, may reveal more detail of a talus-cone stratigraphy. One may also expect the deposits in the westernmost passage of Pixie's Hole, by its closeness, to provide additional data. To further aid the study of the sedimentation, it would be important to determine what may have happened further along the passage to the original Stalagmite Floor 1 and if there are any other levels clearly of Devensian, or later, age on the other side of the suspected talus-cone. Further dating of the stalagmite floors $2 \mathrm{a}$ and $2 \mathrm{c}$ would fix a timeframe for their underlying deposits, i.e. The Reindeer Stratum. The collection of more mammal remains and artefacts in a stratified context would add more to the knowledge of the faunal assemblages and the presence of humans.

Finally a re-investigation of Tramp's Cave and its stream gravel, which are at a lower level in the gorge than both Cow Cave and Pixie's Hole, together with its Palace Quarry extension, would be valuable to determine the possible age of this stratum and further assist in interpreting the geological, speleological, and palaeontological history of the gorge and its caves.

\section{ACKNOWLEDGEMENTS}

Recognition of a great debt of thanks is due to the Late Dr. Antony J. Sutcliffe of the Department of Palaeontology (BMNH) who introduced this writer to Devon cave palaeontology, and suggested the research on Cow Cave. Permission to study Cow Cave was kindly granted by the land owner, Lord Clifford. Funding was provided by the Treacher Fund of the Geologists' Association of London. Time to undertake the research and laboratory assistance was also provided by the Department of Palaeontology of the $\mathrm{BMNH}$. Identification of specimens by staff members of $\mathrm{BMNH}$ is acknowledged. Thanks especially go to Dr. G. Corbet and latterly to Dr. K. Kowalski of the Polish Academy of Science, Kracow who both identified the rodent specimens. Thanks to Don Bramwell for kindly identifying all the bird remains. The Torquay Museum permitted the removal of almost the entire 1927-1934 collection to London for further study, with thanks to then curator, Dr. F. S. Wallis. Further assistance has latterly been provided by the present curator, Barry Chandler. The writer is further indebted to the Torquay Museum and The Natural History Museum, London, for permission to include photographs of specimens within their collections. Excavation materials were loaned by the Institute of Archaeology, London, and the Devon Archaeological \& Exploration Society through Diana Woolner. Special thanks are also due to Mrs. Margaret Neumann (Nee Lambert), formerly of BMNH, for considerable logistical, as well as field, assistance. The writer is also grateful to the many people who assisted during field seasons, including other BMNH staff members, former archaeological students, Ron (now Professor) J. Clarke, amateur archaeologists, members of the Devon Speleological Society, other interested persons and personal friends. Dr. Simon Colcutt kindly read the original 1963 manuscript (now much up-dated) and made various useful comments and suggestions. Latterly, the writer acknowledges the more recent collaboration of Dr. Joyce Lundberg and Dr. Donald McFarlane for field sampling and U-Th dating, with gratitude being especially accorded to Joyce Lundberg for her constructive comments and assistance with this manuscript.

\section{REFERENCES}

Anon. (probably T. Northmore), 1825 - Organic Remains from Kent's Hole and Chudleigh Cave. The Monthly Magazine or British Register, 59: 190-191.

Anon., 1988 - Oxford date list. Archaeometry, 40(2): 437455.

Bell A., 1915 - Pleistocene \& Later Bird Fauna of Great Britain and Ireland. The Zoologist, (Ser.4) 19: 401-412.

Bell A., 1922 - Pleistocene \& Later Birds of Great Britain and Ireland. The Naturalist, Aug-Sept. 1922: 251-253.

Beynon F., 1934 - The Cow Cave, Chudleigh. Trans. \& Proc. Torquay Nat. Hist. Soc., 6(2): 127-132.

Bramwell D., 1963 - Report on the Bird Remains from Cow Cave, Chudleigh, Devon in the Torquay Museum Collection. Unpublished: Torquay Museum Archives. $4 \mathrm{p}$.

Buckland W., 1823 - Reliquiae Diluvianae: or, observations on the organic remains contained in caves, fissures, and diluvial gravel, and on other geological phenomena, attesting to the action of a universal deluge. ( $1^{\text {st }}$ edition) Murray, London, 303p.

Campbell J.B., 1977 - The upper Palaeolithic of Britain a study of man and nature in the late Ice Age. Vol.1. (Oxford: Clarendon Press.) 264p.

Colcutt S. N., 1984 - The Analysis of Quaternary Cave Sediments and its Bearing upon Palaeolithic Archaeology, with special reference to selected sites from Western Britain. Unpublished PhD Thesis. University of Oxford. $1325 \mathrm{p}$.

Fisher C.T. \& Yalden D.W., 2004 - The steppe pika Ochotona pusilla in Britain, and a new northerly record. Mammal Rev. 2004, 34(4): 320-324.

Gilmour M., Current A., Jacobi R., \& Stringer C., 2007 Recent TIMS dating results from British Late Pleistocene vertebrate faunal localities: context and interpretation. Journal of Quaternary Science, 22(8): 793-800.

Hetherington D.A., Lord T.C. \& Jacobi R.M., 2005 - New evidence for the occurrence of Eurasian lynx (Lynx lynx) in medieval Britain. Jn1. Quaternary Sci., 21: 3-8.

Hinton M.A.C., 1926 - Monograph of the Voles \& Lemmings (Microtinae) Living and Extinct. 1: xvi + 488pp. London, British Museum (Natural History).

Holman J.A., 1988 - Herpetofauna of the Late Devensian, early Flandrian Cow Cave site, Chudleigh, Devon. Herpetological Journal, 1: 214-218.

Lundberg J., \& McFarlane D.A., 2008 - Kents Cavern A Field Guide to the Natural History. William Pengelly Cave Studies Trust Ltd., 2008. 44p. 
Lundberg J., Simons J. \& McFarlane D., 2008 - A Pleistocene chronology for the fauna and artefacts of Cow Cave, Devon, UK. Cave \& Karst Science, Trans. British Cave Res. Assoc., 34(3): 101-104.

McEnery Rev. J., 1829-1841. Manuscripts preserved in the library of the Torquay Natural History Museum.

McEnery Rev. J., 1859 - Cavern Researches. 8 ${ }^{\text {th }}$. Ed. Simpkin, Marshal \& Co., London.

Newton E.T., 1923 - Pleistocene Birds' Remains from Chudleigh. The Naturalist, Aug.1923: 264-265.

Northmore T.. in Blewitt O., 1832 - The Panorama of Torquay. $2^{\text {nd }}$. Ed.

Oldham A.D., Oldham J.E.A. \& Smart J., 1972 - The Caves of Devon. Bristol (Privately published), i-xiv + 90p.

Pengelly W., 1873 - The Ossiferous Caverns and Fissures in the Neighbourhood of Chudleigh, Devonshire. Trans. Devon Assoc.. 6: 46-60.

Polwhele Rev. R., 1797 - The History of Devonshire. London. (3 Vols.), Vol.1, Caddell, Johnson and Dilly, London, 504p.

Risdon T., 1811 - The Chorographical Description or Survey of the County of Devon, 1605-1630. Rees and Curtis, Plymouth.[Printed as a genuine copy of the original Ms with additions].

Shaw T.R., 1949a - Survey of the Chudleigh Caves. Devon Spel. Soc. Records. 19 p.
Shaw T.R., 1949b - The Caves at Chudleigh. Report Devonshire Association, 81 : 341- 345.

Simons J. W., 1960 - A New Discovery-Clifford's Cave, Chudleigh. Newsl. Devon Spel. Soc., 66 (March, 1960): 1-3 (Plan).

Simons J. W., 1961 - Further Exploration in Clifford's Cave, Chudleigh. Newsl. Devon Spel. Soc., 72 (June, 1961): 1-3 (Plan).

Simons J. W., 1963 - Successful Fluorescein Tests in Clifford's Cave, Chudleigh, 1961. Newsl. Devon Spel. Soc., 81 (March, 1963): 1-4 (Plan).

Sutcliffe A.J., 1955 - A Preliminary Report on the Reindeer Remains from Banwell Bone-Cave - Antler Bases. Jnl. Axbridge Caving Grp. \& Archeo. Soc., 2(4): 35-40.

Sutcliffe A.J., \& Kowalski K., 1976 - Pleistocene rodents of the British Isles. Bull. British Mus.(Nat.Hist.), 27(2): 1-47.

Sutcliffe A.J. \& Zeuner F., 1962 - Excavations in the Torbryan Caves, Devonshire. Proc. Devon Archaeo. \& Explor. Soc., 5(5-6): 127-145.

Swete Rev. J., 1794 - Picturesque Sketches of Devon 17921801. Vol.8, p.101-109. Unpublished manuscript in the Devon County Record Office, County Hall, Exeter.

Woolner D., 1963 - Tramp's Cave, Chudleigh (SX866786). Newsl. Devon Archeo. \& Explor. Soc., 5 (Sept.1963): 6.

Youings J. 1996 - Some Early Topographers of Devon and Cornwall. In Mark Brayshay, Topographical Writers in South-West England. University of Exeter Press, p.52-58. 